\title{
Mouse Models for Efficacy Testing of Agents against Radiation Carcinogenesis-A Literature Review
}

\author{
Leena Rivina $^{1, *}$ and Robert Schiestl ${ }^{1,2,3}$
}

1 Department of Environmental Health Sciences, University of California, Los Angeles, 650 Charles E. Young Dr. South, CHS 71-295, Los Angeles, CA 90095, USA

2 JCCC Healthy and At-Risk Populations Program Area, Department of Pathology and Laboratory Medicine, University of California, Los Angeles, 650 Charles E. Young Dr. South, CHS 71-295, Los Angeles, CA 90095, USA; E-Mail: rschiest1@mednet.ucla.edu

3 Department of Radiation Oncology, University of California, Los Angeles, 650 Charles E. Young Dr. South, CHS 71-295, Los Angeles, CA 90095, USA

* Author to whom correspondence should be addressed; E-Mail: yrivin@ucla.edu; Tel.: +1-310-267-2593; Fax: +1-310-267-2578.

Received: 6 October 2012; in revised form: 26 November 2012 / Accepted: 11 December 2012 / Published: 27 December 2012

\begin{abstract}
As the number of cancer survivors treated with radiation as a part of their therapy regimen is constantly increasing, so is concern about radiation-induced cancers. This increases the need for therapeutic and mitigating agents against secondary neoplasias. Development and efficacy testing of these agents requires not only extensive in vitro assessment, but also a set of reliable animal models of radiation-induced carcinogenesis. The laboratory mouse (Mus musculus) remains one of the best animal model systems for cancer research due to its molecular and physiological similarities to man, small size, ease of breeding in captivity and a fully sequenced genome. This work reviews relevant M. musculus inbred and $\mathrm{F}_{1}$ hybrid animal models and methodologies of induction of radiation-induced leukemia, thymic lymphoma, breast, and lung cancer in these models. Where available, the associated molecular pathologies are also included.
\end{abstract}

Keywords: radiation carcinogenesis; animal models; radiation protectors; radiation mitigators; secondary cancers 


\section{Introduction}

The number of people diagnosed with cancer each year is growing, as is the number of post-therapy survival rates. Approximately one in two people in the United States will be diagnosed with cancer at some point in their lifetime and about half of them will receive radiation as a part of their therapy regimen [1,2]. Radiation is either administered as a sole curative/palliative agent, in combination with chemotherapeutic drugs, molecular targeted therapy, immunotherapy, or as a part of immune suppression procedure for bone marrow, stem cell and organ transplantation [3]. However, normal healthy tissues are inadvertently exposed to radiation, which may result in a variety of acute toxicities or chronic secondary malignancies. One of such malignancies is radiation-induced cancer $[4,5]$.

In recent years, rapid technological advances in radiation oncology have enabled radiation to be targeted much more precisely to tumor sites reducing some unnecessary exposure of healthy surrounding tissues and increasing both the maximum tolerated doses and the therapeutic ratio [6,7]. However, collateral exposure of normal tissue and potential subsequent malignancy is still unavoidable. Development of biological therapies to supplement technological advances in radiation oncology would present a powerful solution and may further revolutionize the field.

There are three potential classes of agents intended to modulate normal tissue damage: (1) radiation protectors, agents given prior to radiation exposure; (2) radiation mitigators, agents given post-exposure (PE) but prior to the onset of symptoms; and (3) therapies, or agents administered after the onset of symptoms [8]. To date, Amifostine ${ }^{\mathrm{TM}}$ is only agent approved by the Food and Drug Administration (FDA) intended to protect normal tissues during irradiation [9]. To increase the number of available radiation modulating therapies, National Cancer Institute (NCI) in collaboration with the National Institute of Allergy and Infectious Diseases (NIAID) have put forth an algorithm for preclinical and clinical development for agents aimed at decreasing the adverse effects of cancer therapy, including radiation [10]. One of the imperative parts of the proposed algorithm is accurate selection of animal models for therapeutic activity validation. For in-depth review on the selection of NIAD-recommended animal models for the testing of therapies designed to mitigate or treat non-cancer toxicities associated with radiation exposures one can refer to Williams et al. [11]. The purpose of this work is to review select inbred mouse models that may be used in preclinical settings to test the efficacy of agents intended to protect, mitigate, or treat radiation-induced carcinogenesis.

\section{Methods}

\subsection{Research Strategy}

Mus musculus, the laboratory mouse, is one of the best models available for the study of cancer initiation, progression and corresponding pathologies. The laboratory mouse has undergone a significant evolution in its complexity enabling it to mimic more and more precise aspects of the most multifaceted disease of all - cancer. In the researcher's arsenal today are murine models ranging from carcinogen-inducible tumors to xenograft models transplanted with human neoplastic cells to humanized mice that express human genes. New generations of genetically engineered mice (GEM) have been imbued with the ability to accurately recapitulate pathophysiological and underlining molecular features of many human cancers [12]. Genetically homogenous inbred mice used in 
environmentally inducible cancer studies are increasingly neglected in favor of GEMs, often because the inbred mice develop tumors at low frequencies and with variable latencies. Despite these flaws, however, inbred mice are indispensible in the discovery of novel oncogenes, tumor suppressors and preclinical assessment of toxic or therapeutic effects of innumerable agents [13].

We have set out to identify inbred mouse models of radiation-induced (RI) cancers intended for assessment of efficacy in protecting, mitigating or treating these malignancies. We have concentrated on models of leukemia, lung and breast cancers, as these have been identified as the most commonly arising secondary cancers post radiation therapy [5]. Lymphoma has also been included, despite its unconfirmed status as a radiation-induced malignancy in man.

\subsection{Inclusion Criteria}

The scope of this review is limited to murine models of radiation-induced leukemogenesis, lymphomagenesis, breast and lung carcinogenesis following exposure to low-LET gamma- and X-ray radiations with a high total dose and dose-rate. Inductions with high-LET radiation, genetically engineered mice and models that required supplemental treatment are outside of the scope of this work. Only inbred mice whose cancers are inducible with either a single total body irradiation (TBI) or fractionated targeted exposures are described, the only exception being an orthograft radiation chimera model of breast cancer. Lastly, only murine models mimicking underlying molecular pathologies observed in man are included.

\section{Results and Discussion}

\subsection{Radiation-Induced Leukemia}

Leukemia was one of the few cancers recognized as a radiation-induced malignancy quite early in the development of the field of radiation biology. Before any radiation safety standards were introduced, many X-ray workers, mostly physicists and engineers, developed leukemia after working near accelerators and other ionizing radiation (IR) sources. However, much more than anecdotal correlation between radiation exposure and increased leukemia incidence and mortality began emerging as the reports from Life Span Study cohorts following Japanese atom-bomb survivors and patients receiving high doses of therapeutic radiation for cervical cancers, tinea capitis and ankylosing spondylitis began to be published [5,14-19]. In a large study conducted by Boice and colleagues, the risk of secondary malignancies following radiation treatment for the uterine cervix carcinoma established as a sharp increase in leukemia incidence following irradiation [20]. In the last decades, more reliable data from the Chernobyl disaster on excess risk estimates of leukemia in adults and children also began to emerge, providing a more complete data set on age-dependence, doses and latencies [21-24].

Despite the differences in exposure scenarios, irradiation dose-rates and doses, and radiation quality components, there are salient features common to all reported IR-induced leukemias. Acute and chronic myeloid leukemia (AML and CML, respectively) are the two most common radiation-induced cancers observed in the adult human population [15,16,18,25-27]. Children exposed at 5-9 years of age appear to be more susceptible to acute lymphocytic leukemia (ALL), while older children are more 
likely to develop AML. Chronic lymphocytic leukemia (CLL) does not seem to be influenced by radiation [14]. The risk of developing leukemia is highest within the first decade following exposure and begins to decrease as time goes on, but never quite returns to baseline risk [15,16,21,26,28]. In some reports, sex differences have been reported in radiation-induced leukemia instances [16,18,21,25].

Epidemiological data, however, cannot tell the whole story about radiation-induced leukemogenesis. The use of mouse models becomes imperative to study the mechanism of induction, improve diagnostics, and further radiation protection, therapy and mitigation efforts. Today a few established IR-induced leukemogenesis murine models exist: RF [29,30], SJL/J [31], CBA [32,33], and C3H/He [34]. Table 1 summarizes the optimal methods of induction and the associated myeloid leukemia (ML) frequencies.

Table 1. Induction of myeloid leukemia in mice with low-LET ionizing radiation.

\begin{tabular}{|c|c|c|c|c|c|c|c|c|}
\hline Malignancy & $\begin{array}{l}\text { Mouse } \\
\text { Strain }\end{array}$ & Age & Sex & $\begin{array}{c}\text { Mode of } \\
\text { Induction }\end{array}$ & Latency & $\begin{array}{c}\text { Spontaneous } \\
\text { Frequency }\end{array}$ & $\begin{array}{c}\text { Induced } \\
\text { Frequency }\end{array}$ & Ref. \\
\hline $\begin{array}{l}\text { Myeloid } \\
\text { Leukemia }\end{array}$ & $\begin{array}{c}\mathrm{RF}(\mathrm{RF} / \mathrm{J}, \\
\mathrm{RFM})\end{array}$ & 8 weeks & Male & $4.25 \mathrm{~Gy}$ & 4-12 months & $2-4 \%$ & $50-90 \%$ & {$[30]$} \\
\hline $\begin{array}{l}\text { Myeloid } \\
\text { Leukemia }\end{array}$ & $\mathrm{SJL} / \mathrm{J}$ & $8-10$ weeks & Female & 3-3.5 Gy & 12 months & $0 \%$ & $10-30 \%$ & [31] \\
\hline $\begin{array}{c}\text { Myeloid } \\
\text { Leukemia }\end{array}$ & $\mathrm{C} 3 \mathrm{H} / \mathrm{He}$ & $8-10$ weeks & Male & $2.84 \mathrm{~Gy}$ & $1.5-18$ months & $<1 \%$ & $25 \%$ & {$[34]$} \\
\hline $\begin{array}{l}\text { Myeloid } \\
\text { Leukemia }\end{array}$ & $\begin{array}{c}\mathrm{CBA} \\
(\mathrm{CBA} / \mathrm{Ca}, \\
\mathrm{CBA} / \mathrm{Cne}, \\
\mathrm{CBA} / \mathrm{H})\end{array}$ & $12-15$ weeks & Male & $3 \mathrm{~Gy}$ & 18-24 months & $<1 \%$ & $\sim 25 \%$ & {$[32,33]$} \\
\hline
\end{tabular}

\subsubsection{RF Mouse}

The RF mouse was developed at the Rockefeller Institute as a general-purpose stock from A, R, and S strains $[30,35,36]$. Its propensity for radiation-induced leukemogenesis has been extensively studied by Upton and colleagues [37]. One of the earliest accounts of leukemogenesis in these mice dates back to 1936 with detonation experiments conducted by Furth and colleagues [38]. Myelogenous or myeloid leukemia (ML) in the RF model is inducible with a single dose of ionizing radiation and has been proposed as a valid counterpart to human AML, particularly due to its prolonged preclinical period with diagnosable pre-cancerous tissue lesions [30].

Background incidence of myeloid leukemia in RF mice is $2-4 \%$ and appears later in life, at around 18-24 months of age [39]. Exposure of 8-week old RF males to 1.5 Gy increases ML frequency to about $40 \%$ while in utero and neonatal exposures actually decrease ML induction [29,40]. At the dose of 4.25 Gy ML incidence increases to 50-90\%, with a latency period of 4-12 months [30,37,41]. As early as 12 weeks post exposure, an enlarged spleen and liver accumulate young myeloid cells. Clinically, RF leukemia presents with infiltration to peribronchial areas, lymph nodes, and gastrointestinal lymphoid organs. However, at the same dose the induction of thymic lymphoma also increases to about $25 \%$, which can potentially interfere with accurate ML diagnosis and modeling of 
the human disease [30]. Upton et al. have also demonstrated a sex difference in susceptibility to TL and ML: females are more susceptible to TL, while males are more likely to develop ML [29].

Hayata et al. reported that, similarly to radiation-induced leukemia in the SJL/J mouse [42], myeloid leukemia in the RF model exhibits partial deletion of chromosome \#2 along with other genomic instabilities including loss of the Y-chromosome [43]. Some researchers have suggested that the protracted latency of ML in RF mice correlates with the data from Japanese A-bomb survivors and children exposed in the Chernobyl disaster, with the corresponding peak incidence in leukemia 5-10 years following the irradiation event $[16,21,25,44]$. One drawback of the RF mouse model is the fact that it often presents with mixed hematopoietic tumors of myeloid leukemia and thymic lymphoma [29].

\subsubsection{SJL/J Mouse}

Developed in the 1960s by Murphy, the SJL/J strain is known for its high spontaneous frequency of reticulum cell neoplasms (type B, RCN B) $[45,46]$ that occur at roughly 380 days of age in both males and females. The histological pattern observed in the RCN B was similar to that of Hodgkin's disease in human beings, leading to the proposal for its use as an investigative model of such lesions [47].

Single exposure of 8-10-week old female SJL/J mice to 3.0-3.5 Gy of whole-body irradiation induces myeloid leukemia in $10-30 \%$ of treated animals within a year. However, Haran-Ghera and Kotler have also observed that SJL/J exposure to fractionated X-rays induces lymphosarcomas [47]. Consistent with AML diagnosis, leukemic infiltrations are observed in the bone marrow, lymph nodes, spleen and liver [31]. The frequency of radiation-induced acute myeloid leukemia (RI-AML) increases with age up to about 12 weeks during the time of irradiation. Such an increase is possibly explained by the sensitivity of the developing mononuclear phagocytic system [48].

While radiation appears to initiate the progression of RI-AML, this multiphase malignancy often requires additional promoting factors for tumor development [49]. Preleukemic cells and the characteristic chromosome 2 deletions are observed in the overwhelming majority of bone marrows of IR-treated mice prior to overt AML clinical presentation (90-120 days) [50,51]. Additionally, administration of corticosteroids following irradiation increases RI-AML incidence to 50-70\% [31]. Administration of growth factors, especially colony stimulating factor-1 (CSF-1), decreases latency and increases frequency to $75 \%$ [49,52]. In fact, 2-4 months prior to RI-AML onset, preleukemic $\mathrm{RJL} / \mathrm{L}$ mice have significantly elevated CSF-1 levels as compared to mice that fail to develop RI-AML or those that develop RCN B. RI-AML cells in vitro synthesize significant amounts of CSF-1, further supporting CFS-1 necessity for leukemia progression in addition to IR [48].

Clinical presentation of RI-AML in SJL/J mouse resembles that of secondary leukemias observed in man [31]. Patients in remission after radiation and steroid treatment for Hodgkin's disease often develop AML similar to those described in SJL/J mice [53-55]. Additionally, elevated circulating levels of CSF-1 have been reported in neoplastic malignancies including AML and appear to be associated with poor prognosis [56-59], further supporting the use of the SJL/J mouse for the study of CSF-1's role in cancer. 


\subsubsection{C3H Mouse}

Strong developed the $\mathrm{C} 3 \mathrm{H}$ strain in 1920 from a cross of the Bragg Albino mouse and the DBA mouse, specifically selecting for elevated incidence of mammary tumors (MT). Ninety percent of unfostered pups (pups remaining with mother postpartum) develop mammary tumors by 11 months of age. Fostering the offspring or transferring fertilized ova to a mammary tumor virus-free surrogate significantly reduces tumor frequency $[35,36]$. Fostered $\mathrm{C} 3 \mathrm{H} / \mathrm{He}$ substrain has a high incidence of spontaneous hepatomas later in life [34,60].

$\mathrm{X}$-irradiation of $8-10$ week old male $\mathrm{C} 3 \mathrm{H} / \mathrm{He}$ mice with 3 Gy TBI induces myeloid leukemia in $23.9 \%$ of exposed animals, with myelomonocytic leukemia being the most prevalent subtype. Dose-response curves for $\mathrm{C} 3 \mathrm{H}$ mice are similar to those for RFM and CBA mice: there is a proportional increase in the frequency of leukemia induction until a critical dose of around $3 \mathrm{~Gy}$, after which the incidence spontaneously drops off [32]. Spontaneous incidence of leukemia is less than 1\% [34].

Yoshida et al. reported a significant sex difference, with females being less susceptible to RI-ML than males of the same age. Administration of the synthetic glucocorticoid prednisolone following irradiation of $\mathrm{C} 3 \mathrm{H} / \mathrm{He}$ mice increases the incidence of $\mathrm{ML}$ to $38.5 \%$ in a similar fashion to that of $\mathrm{SJL} / \mathrm{J}$ mice [31]. The mechanism of induction is suspected to involve suppression and promotion of hematopoietic recovery. Reducing daily caloric intake by roughly a third eliminates spontaneous ML entirely and decreased the incidence of RI-ML to $7.9 \%$ when the restriction started before 6 weeks of age or to $10.7 \%$ when the restriction started post exposure (PE) at 10 weeks of age [61]. Caloric restriction also promoted PE longevity via insulin pathway modulation [62]. Chronic inflammation may also be implicated as an exacerbating and possibly a leukemogenesis-promoting factor. In later studies Yoshida demonstrated that inducing chronic low-level inflammation by inserting a cellulose acetate membrane increases RI-ML incidence to $35.9 \%$ [63].

As with the RFM and SJL/J mice, partial deletion of chromosome 2 has been implicated in RI-AML in $\mathrm{C} 3 \mathrm{H} / \mathrm{He}$ mice $[43,64]$. As early as $24 \mathrm{~h} \mathrm{PE}$, during the first metaphase, chromosome 2 deletions are detectable in the bone marrow in the $\mathrm{C} 3 \mathrm{H} / \mathrm{He}$ mouse, suggesting that chromosome 2 deletions act in the initiation stages of leukemogenesis [65]. Some researchers have compared human $\mathrm{Ph}^{1}$ chromosome transformations in chronic myeloid leukemia to mouse chromosome 2 aberrations in its incidence and disease specificity $[66,67]$.

\subsubsection{CBA Mouse}

The CBA mouse is a cross between a Bragg albino female and a DBA male originally developed by Strong in 1920 with low mammary tumor incidence. Males of CBA/Ca substrain tend to have a shorter lifespan than $\mathrm{CBA} / \mathrm{Ca}$ females $[35,36]$. Both $\mathrm{CBA} / \mathrm{Ca}$ and $\mathrm{CBA} / \mathrm{H}$ are direct substrains of the original CBA mouse derived in the United Kingdom [68,69].

A 3.0 Gy TBI irradiation with either gamma- or X-rays of 12-week old male CBA/H mice results in $25 \%$ induction of myeloid leukemia. Infiltration of the sternal bone marrow, liver, and spleen are observed and serve as diagnostic endpoints [32,33]. As previously mentioned, the dose-response curve is curvilinear, implying a threshold dose similar to that of man-leukemia is rarely observed in cases with high exposure [70,71]. 
As with the other mouse models of RI-ML, chromosome 2 aberrations have been reported and correlated with myeloid leukemia in the CBA mouse [69,72,73]. From as early as 20 hours to as late as 24 months PE, expansion of cells carrying chr2 lesions is observed in 20-25\% of irradiated mice [74]. Bouffler et al., however, weren't able to conclude that the induction of chr2 aberrations and presence of an aberrant chr2 clone can accurately predict development of RI-AML in CBA mice [75]. Aberrations on chromosome 4 in about $50 \%$ of $\mathrm{CBA} / \mathrm{H}$ mice diagnosed with typical AML were also reported. Cleary et al. have identified the Lyr2/TLSR5 allele as a likely mutation candidate for radiation-induced hematopoietic malignancies including the myeloid and lymphoid mouse leukemias [76]. Susceptibility to RI-AML in CBA/H has also been linked to an $8 \%$ decrease in DNA-methylation not observed in the AML-resistant strain C57B1/6 [77].

The CBA mouse is the current favorite RI-AML model for human AML for a few reasons: (1) it has a low spontaneous frequency of AML, (2) it has a favorable mean latency of 18 months, and (3) morphologically CBA AML resembles the human malignancy [68,78]. Dekkers et al. have also suggested that the two-step mutation model of RI-AML in $\mathrm{CBA} / \mathrm{H}$, extrapolated from X-ray and neutron data, has application in animal modeling of human RI-AML [79].

\subsubsection{ML-Associated Molecular Pathologies}

For over 30 years, deletions on chromosome 2 have been linked to AML in murine models across multiple strains $(\mathrm{RF}, \mathrm{C} 3 \mathrm{H} / \mathrm{He}, \mathrm{CBA}$, and $\mathrm{SJL} / \mathrm{J})[42,43,64]$. Due to the specific nature of the chromosome aberrations on chr2, the loss of a tumor suppressor gene seemed a more likely scenario than an oncogene activation [80]. In 2004 Cook and colleagues identified the sfpil gene encoding a transcription factor PU.1 from the 2 Mbp commonly deleted region on chr2 [80-82].

PU.1/Sfpi-1 is an important player in hematopoiesis and is involved in promotion, differentiation and regulation of all hematopoietic lineages. It's essential for terminal myeloid (macrophages and neutrophils) cell differentiation and stem cell maintenance [83-87]. In mice, PU.1 function is important for leukemic transformations in myeloid cells; in humans its importance in such transformations is still actively debated $[81,88,89]$. PU.1 has a DNA binding domain, engages in protein-protein interactions and has regulatory phosphorylation sites imperative for its function [90].

In addition to the loss of PU.1 on one chr2, the second copy of PU.1 is often inactivated by point mutations in the DNA binding region [81,88]. Homozygous conditional knockdown of PU.1 (expressing $\sim 20 \%$ of WT levels) induces AML in mice by 3-8 months of age [91] and myeloid leukemia when inactivated in adult mice [92]. In transgenic mice expressing oncoprotein PML-PAR, loss of genomic region coding for PU.1 is a common secondary event in leukemogenesis [93]. Upregulation of $c-M y c$ has also been reported in AML cells accompanying PU.1 deficiencies [94]. Cook et al. have demonstrated that expression of PU.1 at WT levels in promyelocytic leukemia cells inhibited clonogenic growth, forced monocytic differentiation, and induced apoptosis. All of these findings suggest that suboptimal expression of PU.1 can provoke and promote leukemogenesis by blocking maturation of the cell $[81,87]$. Peng et al. have also suggested that quantification of PU.1-deleted bone marrow cells may be used as a surrogate marker for RI-AML [95].

In humans a homologue of PU.1 exists on chromosome 11 [87] and is expressed at low levels in most AML cases [96]. However, direct inactivation by deletion of PU.1 is very rare [88,89]. Cook 
proposes that other mechanism of PU.1 inactivation in human AML might be at play: the gene might be silenced epigenetically, through protein-protein interaction or via interaction with a mutated receptor (i.e., Flt3 cytokine receptor that are found in $25 \%$ of human AML) [81]. Interestingly, Finnon et al. have recently shown that Flt3-ITD and Sfpi1/PU.1 mutations are mutually exclusive in murine radiation-induced AML without any overt phenotypic differences [97]. The group has not reported actual levels of PU.1 in these RI-AMLs, so it is plausible that the PU.1 depression is still involved in these malignancies.

It remains unclear, however, whether radiation is responsible for one or both genomic events observed in RI-AML: deletion of PU.1 on chr2 and Sfpil mutations in its DNA-binding domain. Data suggests that IR induces chr2 deletions [51,64,95], but it remains undetermined whether the deletion is a result of direct DNA damage or induced through delayed genomic instability [98-100]. Radiation, however, is not a likely candidate for the direct alteration of the second PU.1 allele in RI-AML cells, as IR does not induce point mutations observed in Sfpi1 [81,88,94]. Point mutations are the most common type of spontaneous mutations and evidence suggest that Sfpil mutations are of spontaneous origin [101,102].

Ban and Kai demonstrated that replicative stress applied to hematopoietic stem cells (HSC) surviving 3 Gy radiation contributes to the HSC's accelerated aging, thus decreasing replicative fidelity of the genome and increasing the rate of mutation accumulation, including mutations in the remaining copy of the Sfpil gene. A mathematical model fitted to experimental data from cobblestone area forming cells (CAFC) and colony forming unit-granulocyte/macrophages (CFU-G/M) on ex vivo bone marrows revealed that irradiated HSCs cycle as much as ten times more quickly than those from unexposed animals [102]. Such increase in cycling is thought to also appear in vivo after irradiation.

Hirouchi et al. have recently challenged the commonly accepted paradigm that the HSC is the targeT cell of RI-AML [78] and concluded that AML stem cells can arise from long-lived HSCs as well as the short-lived multipotent progenitors (MPPs) and common myeloid progenitors (CMPs) that have acquired self-renewal potential. The cell surface phenotypes and gene expression profiles of AML stem cells in the study closely resembled those of normal CMPs rather than those of HSCs [103].

In addition to chr2, critical loci on chromosomes 8,13 , and 18 have also been identified. On chr18 resides $R b b p 8$ gene that encodes for the CtIP protein. CtIP is upregulated in response to X-ray exposure in the RI-AML-sensitive CBA mice but not in the RI-AML-resistant C57BL/6 and is a suspected tumor suppressor. Aberrant human chromosome segments bearing Rbbp 8 gene have been reported in many cancers including AML [104].

\subsection{Radiation-Induced Lymphoma}

Debate is still ongoing regarding the causal effect of ionizing radiation on lymphomagenesis in man. While Hartge and colleagues concluded that IR probably causes lymphoma and a small increase in risk between radiotherapy and lymphoma has been identified [105,106], a plethora of investigators tend to disagree. Some investigators found the link between non-Hodgkin's lymphoma (NHL) and radiotherapy extremely weak, and no association at all between IR and Hodgkin's disease [16,107-109]. Recent data, however, seem to suggest that the causal link is real. Richardson et al. have published data supporting a strong link between ionizing radiation and lymphoma mortality among radiation 
workers exposed at the Savannah River Site in South Carolina. The basis for disagreement among researchers appears to be the disease's protracted latency and obscure mechanism of induction [110].

Historically, in rodent pathology classification no distinction was made between lymphomas and lymphocytic leukemias. Malignant lymphomas in mice can be placed into six subdivisions with further modifiers depending on the site of the tumor-thymic, mesenteric, and leukemic [111]. Most of the time murine lymphoma is diagnosed phenotypically: labored breathing, hunched posture, and the enlargement of spleen and lymph nodes are indications of fulminant malignancy. Mice with labored breathing but without enlarged spleens and lymph nodes are usually classified as thymic lymphomas [112]. Immunological markers and morphologic criteria are also commonly used in more specific diagnosis [113-115]. Immunophenotypes of thymic lymphoma in mice closely resemble their counterparts in humans despite the fact that there is no direct human analog of thymic lymphoma [115].

Thymic lymphoma (TL) in mice has been extensively studied as a model of radiation-induced carcinogenesis since it was first described by Kaplan et al. in 1953 [116]. In addition to C57BL/6 and other C57BL substrains, BALB/c and NSF are also susceptible to RI-TL [117,118] (See Table 2 for summary).

Table 2. Induction of thymic lymphoma in mice with low-LET ionizing radiation.

\begin{tabular}{|c|c|c|c|c|c|c|c|c|}
\hline Malignancy & Mouse Strain & Age & Sex & $\begin{array}{c}\text { Mode of } \\
\text { Induction }\end{array}$ & Latency & $\begin{array}{c}\text { Spontaneous } \\
\text { Frequency }\end{array}$ & $\begin{array}{c}\text { Induced } \\
\text { Frequency }\end{array}$ & Ref. \\
\hline $\begin{array}{c}\text { Thymic } \\
\text { Lymphoma }\end{array}$ & $\begin{array}{c}\text { C57BL } \\
(\mathrm{C} 57 \mathrm{BL} / 6, \\
\text { C57BL/6J) }\end{array}$ & $\begin{array}{c}\text { 4-6 } \\
\text { weeks }\end{array}$ & $\begin{array}{c}\text { Male, } \\
\text { Female }\end{array}$ & $\begin{array}{c}4 \text { fractions } \\
\text { of } \sim 1.7 \text { Gy } \\
\text { once a week }\end{array}$ & $\begin{array}{c}3-6 \\
\text { months }\end{array}$ & $<1 \%$ & $>90 \%$ & $\begin{array}{l}{[116,} \\
119, \\
120]\end{array}$ \\
\hline $\begin{array}{c}\text { Thymic } \\
\text { Lymphoma }\end{array}$ & $\begin{array}{c}\mathrm{BALB} / \mathrm{c} \\
(\mathrm{BALB} / \mathrm{cHeA})\end{array}$ & $\begin{array}{c}4 \\
\text { weeks }\end{array}$ & $\begin{array}{c}\text { Male, } \\
\text { Female }\end{array}$ & $\begin{array}{c}4 \text { exposures } \\
\sim 1.7 \mathrm{~Gy} \\
\text { once a week } \\
\text { for } 4 \text { weeks }\end{array}$ & $\begin{array}{l}2.5-9.5 \\
\text { months }\end{array}$ & $\begin{array}{c}5-6 \% \\
\text { females; } \\
0 \% \text { males }\end{array}$ & $\begin{array}{c}77 \% \\
\text { (Females) } \\
86 \% \text { (Males) }\end{array}$ & $\begin{array}{l}{[112,} \\
117]\end{array}$ \\
\hline $\begin{array}{c}\text { Thymic } \\
\text { Lymphoma }\end{array}$ & NFS & $\begin{array}{c}4 \\
\text { weeks }\end{array}$ & $\begin{array}{c}\text { Male, } \\
\text { Female }\end{array}$ & $\begin{array}{c}4 \text { fractions } \\
\sim 1.7 \mathrm{~Gy} \\
\text { once a week } \\
\text { for } 4 \text { weeks }\end{array}$ & $\begin{array}{c}\text { 3-6 } \\
\text { months }\end{array}$ & $\begin{array}{l}>1 \% \text { within } \\
12 \text { months }\end{array}$ & $\begin{array}{c}90 \% \\
\text { (females) } \\
89 \% \text { (males) }\end{array}$ & $\begin{array}{l}{[121,} \\
122]\end{array}$ \\
\hline
\end{tabular}

\subsubsection{C57BL Mouse}

C57BL mice were developed in 1921 as a cross between female 57 and male 52 from Miss Abbie Lanthrop stock. It is one of the most widely used mouse stocks in the laboratory. Up to $7 \%$ of C57BL/6 mice develop spontaneous leukemia [36,123].

As early as 1949, Sacher and Brues were able to induce thymic lymphoma in mice with X-ray radiation [124]. In 1952 Kaplan et al. published a seminal paper identifying optimal fractionation periods for TL induction at 8-day intervals for 4 weeks in C57BL mice that results in 93\% disease penetrance within $\sim 250$ days following the first irradiation. Females were identified to be slightly but significantly more susceptible than males to TL at $58 \%$ versus $47 \%$, respectively. Lungs and peripheral lymph nodes seem to be affected in the majority of murine lymphoma cases [119]. TL with similar 
frequencies and latency periods can be induced in C57BL/6, C57BL/10 and C57BL/Ka substrains of C57BL $[120,125,126]$.

Radiation-induced thymic lymphoma (RI-TL) is highly asynchronous and lymphoma cells have been often staged by the presence of MEL-14 $4^{\text {hi }}$ (lymphocyte homing receptor), $\mathrm{H}-2 \mathrm{~K}^{\text {hi }}$ (histocompatibility antigen), and IL-2R (interleukin 2 receptor) surface markers on thymus cortical cells. In the normal adult thymus less than $3 \%$ of the cells in the cortex express MEL-14 ${ }^{\text {hi }}$ or IL-2R ${ }^{+}[127,128]$ and the presence of MEL-14 ${ }^{\text {hi }}$ may signify appearance of a leukemic clone [129]. Additionally, most of the TL tumors bear T-lymphocyte specific antigens Thy-1, Lyt-1, and Lyt-2 [130,131].

The most detected early chromosome abnormality observed in IR-induced thymic lymphoma in C57BL mice is trisomy of chromosome 15 , detected in $65-71 \%$ of case $[132,133]$. Chromosome 15 trisomy is one of the most common cytogenic abnormalities in murine cancers as it leads to amplification of the oncogene myc, deregulation of which might be important in TL [134,135]. Alteration of $m y c$ expression through a translocation is observed in nearly all Burkitt's lymphoma (BL) cases in man. Myc is an oncogene and a transcriptional factor regulating apoptosis; its deregulation has been observed in many cancers in addition to BL [136]. Activation of N-ras and K-ras has also been reported in just over 50\% of RI-TL case in C57BL/6J [128,137]. Inactivation of tumor suppressor $p 53$ does not seem to be a salient feature of RI-TL in C57BL/6 mice [135] but transgenic $p 53$ knockout mice do exhibit higher frequency of RI-TL and implicate another tumor suppressor Pten [138].

\subsubsection{BALB/c Mouse}

$\mathrm{BALB} / \mathrm{c}$ is an inbred strain acquired by Bagg in 1913 and further expanded by Snell in 1932, who has subsequently added the /c designation to reflect the "color" homozygous color locus. It is among one of the most commonly used strains and purportedly does not develop lymphatic leukemia, but is sensitive to radiation lethality [36].

Following the Kaplan et al. methodology, thymic lymphoma can be induced in BALB/c mice with fractionated radiation $(1.7 \mathrm{~Gy} /$ fraction, four fractions total) beginning at 4 weeks of age in both male and female mice at $86 \%$ and $77 \%$, respectively. Later in life, females exhibit a spontaneous frequency of lymphoma at $5.5 \%$ but males do not. The mean latency for both sexes is $\sim 5$ months after IR $[112,117]$.

The majority of studies on the mechanism of lymphomagenesis have been historically worked out either in $\mathrm{C} 57 \mathrm{BL} / 6$ and its substrains or in hybrids that have included a BALB/c parent mated with a strain resistant to radiation-induced lymphoma. Recently, however, the inbred BALB/c mice have been used to demonstrate the role of microRNA (miRNA) in radiation-induced lymphomagenesis. Liu et al. concluded that in RI-TL tissues tumor suppressor gene Big-h3 is downregulated while miR-21 is upregulated. MiR-21 is likely to directly target Big-h3 by inhibiting translation in a 3' UTR dependent manner [139]. 3' UTR dependent manner assumes a specific binding of miRNA to mRNA targets in the 3' untranslated region (3' UTR) [140]. 


\subsubsection{NFS Mouse}

NFS is an inbred strain derived from the outbred NIH Swiss-Webster introduced to Japan in 1972. Maintained in sister-brother mating its current designation is NFS or NIH Swiss/S. The strain is also available in the United States [118].

Thymic lymphoma in NFS mice is induced in the same fashion as in BALB/c and C57BL mice: 4 weekly irradiations of 1.7 Gy beginning at one month of age. Both males and females are susceptible with comparable frequencies but the latency in males is longer (167 vs. 208 days). Spontaneous frequency is also low at less than $10 \%$ at 600 days of age [118]. Thymectomy on pre-irradiated NSF animals reduces the incidence of TL but increases the incidence of nonthymic lymphomas and leukemias in $67 \%$ of treated mice. Nonthymic lymphomas were predominantly observed in the spleen and mesentery lymph nodes and were most likely of B-cell origin [121]. Perhaps, thymectomies prior to irradiation might provide for a more relevant model of human lymphoma.

\subsubsection{TL-Associated Molecular Pathologies}

From the 1980 s on the use of hybrid models in radiation-induced thymic lymphoma studies became more common as it allowed for easier detection of underlying molecular pathologies. Popular hybrids included $(\mathrm{C} 57 \mathrm{BL} / 6 \mathrm{~J} \times \mathrm{BALB} / \mathrm{c}) \mathrm{F}_{1}, \mathrm{~B} 6 \mathrm{C} 3 \mathrm{~F} 1(\mathrm{C} 57 \mathrm{BL} / 6 \mathrm{~J} \times \mathrm{C} 3 \mathrm{H}) \mathrm{F}_{1}, \mathrm{C} 3 \mathrm{~B} 6 \mathrm{~F} 1$

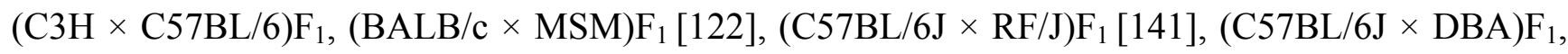
$\mathrm{CBA} / \mathrm{H} \times \mathrm{C} 57 \mathrm{BL} / 6[142,143]$ and the $\mathrm{CXS}$ series of recombinant inbred strains derived from TL-susceptible BALB/cHeA and TL-resistant STS/A [112]. The frequencies of RI-TL in the hybrids between highly susceptible strains and those with low susceptibilities (e.g., BALB/c $\times$ MSM) are usually between the expected frequencies of the parental strains. However, at times the hybrid mice require higher radiation doses in the four weekly fractions, i.e., 2.5 Gy instead of the usual 1.7 Gy [122]. The use of these hybrids has elucidated the importance of such molecular players as Ikaros/Znflal [144,145], BCL11B/Rit1 [146], p73 [147], p19/ARF [148], and inactivation of p15/INK4b(Cdkn2b) and p16/INK4a(Cdkn2a) [149] in radiation-induced lymphomagenesis. Ikaros/Znflal protein is encoded by the $I k z f l$ gene and has many functions including immune system development and regulation of hematopoietic differentiation. In recent years downregulation of Ikaros activity has been established as the most clinically relevant tumor suppressor in B-cell acute lymphoblastic leukemia (B-ALL) and its downregulation associated with poor prognosis [150]. BCL11B/Rit1 (B-cell CLL/lymphoma 11b) belongs to the largest family of transcription factors, the Kruppel-like $\mathrm{C} 2 \mathrm{H} 2$ type zinc finger transcription proteins, and is involved in T-cell differentiation. BCL11B is also a tumor suppressor and is reportedly downregulated in $10-16 \%$ of T-cell acute lymphoblastic leukemias (T-ALL) $[151,152]$. $p 73$ is a member of the $p 53$, pro-apoptotic tumor suppressor family [153]. Low levels of $p 73 \mathrm{mRNA}$ have been reported in non-Hodgkin's lymphoma (NHL) but not in reactive hyperplasia patients. $p 73$ inactivation in NHL cases appears to be due to aberrant methylation of its promoter [154]. Inactivation of cyclin dependent kinase inhibitors from the INK4 family (ARF, p15, and p16) have been reported in Non-Hodgkin's and Burkitt's lymphoma cases [155,156]. Table 3 summarizes the most relevant molecular pathologies observed in radiation-induced thymic lymphoma in mice. 
Table 3. Relevant molecular pathologies in murine RI leukemia and lymphoma.

\begin{tabular}{|c|c|c|c|c|}
\hline Mouse Strain & Malignancy & Molecular Pathology & Role in Cancer & Ref. \\
\hline $\begin{array}{c}\mathrm{RF} ; \mathrm{SJL} / \mathrm{J} \\
\mathrm{C} 3 \mathrm{H} / \mathrm{He} ; \mathrm{CBA}\end{array}$ & $\begin{array}{l}\text { Myeloid } \\
\text { Leukemia }\end{array}$ & $\begin{array}{c}\text { Chr2 deletions: loss of } \\
\text { PU.1/Sfpilon one chr2 copy; } \\
\text { inactivation on the second } \\
\text { copy }\end{array}$ & $\begin{array}{l}\text { Oncogene and transcriptional } \\
\text { regulator of myeloid promoters } \\
\text { PU.1 suppression linked to } \\
\text { leukemic transformation in } \\
\text { mice and men }\end{array}$ & $\begin{array}{c}{[80-82,88,} \\
89]\end{array}$ \\
\hline C57BL & $\begin{array}{c}\text { Thymic } \\
\text { Lymphoma }\end{array}$ & $\begin{array}{c}\text { Trisomy of chr15: } m y c \\
\text { implicated }\end{array}$ & $\begin{array}{c}\text { Oncogene and transcription } \\
\text { regulator of many cell events } \\
\text { including apoptosis } \\
\text { —Almost ubiquitous deregulation } \\
\text { in Burkitt's lymphoma }\end{array}$ & [131-134] \\
\hline \multirow{4}{*}{$\begin{array}{c}\text { Hybrids } \\
\text { between } \\
\text { C57BL/6, C3H, } \\
\text { BALB/c, } \\
\text { MSM, and } \\
\text { RF/J, CBA, } \\
\text { DBA, and the } \\
\text { CTX }\end{array}$} & \multirow{4}{*}{$\begin{array}{c}\text { Thymic } \\
\text { Lymphoma }\end{array}$} & Loss of Ikaros/Znflal activity & $\begin{array}{l}\text { Gene expression regulation and } \\
\text { chromatin remodeling in } \\
\text { hematopoietic differentiation } \\
\text { One of the most clinically- } \\
\text { relevant tumor suppressors in } \\
\text { acute lymphoblastic leukemia } \\
\text { (B-ALL) }\end{array}$ & $\begin{array}{l}{[144,145]} \\
{[121,150]}\end{array}$ \\
\hline & & Loss of $B C L 11 B /$ Rit1 activity & $\begin{array}{c}\text { Transcription factor and tumor } \\
\text { suppressor } \\
\text { Linked to T-cell acute } \\
\text { lymphoblastic leukemia (T-ALL) }\end{array}$ & $\begin{array}{c}{[146,151,} \\
152]\end{array}$ \\
\hline & & Loss of $p 73$ activity & $\begin{array}{c}\text { p53 family tumor suppressor } \\
\text { Abrogated expression in } \\
\text { non-Hodgkin's lymphoma }\end{array}$ & $\begin{array}{c}{[147,153,} \\
154]\end{array}$ \\
\hline & & $\begin{array}{c}\text { Loss of } p 19 / A R F, p 15 / I N K 4 b \\
(C d k n 2 b) \text { and } p 16 / I N K 4 a \\
(C d k n 2 a) \text { activity }\end{array}$ & $\begin{array}{c}\text { Cyclin dependent kinase } \\
\text { inhibitors that restricT cell cycle } \\
\text { progression at } \mathrm{G}_{1} \\
\text { Non-Hodgkin's and Burkitt's } \\
\text { lymphomas }\end{array}$ & $\begin{array}{c}{[142,148} \\
149,155 \\
156]\end{array}$ \\
\hline
\end{tabular}

Transgenic expression of activated Notch1 in murine lymphocytes induces lymphomagenesis [157]. Activation of Notch1 and inactivation of Notch2, paired with overexpression of $c-M y c$ and defective Znfnlal/Ikaros has been reported in $81.25 \%$ of RI-TL suggesting their molecular collaboration in lymphomagenesis [158]. Additionally, the use of hybrids has elucidated recurring chromosomal aberrations on chromosomes 4, 11 and 12, but these aberrations do not appear ubiquitously in all hybrids (e.g., BALB/C $\times$ MSM does not show LOH on chr 4 but C57BL/6J $\times$ RF/J does) [143]. Saito et al. have reported a specific susceptibility locus near D4Mit12 on chromosome 4, as well as loci at D2Mit15 (chr2) and D5Mit15 (chr5). [122]. Piskorowska and colleagues identified additional susceptibility loci at a sex-dependent locus on chr10 (D10Mit134), and chr12 (D12Mit52I) [159].

Hybrids between $\mathrm{C} 57 \mathrm{BL} / 6$ and $\mathrm{C} 3 \mathrm{H}(\mathrm{C} 3 \mathrm{~B} 6 \mathrm{~F} 1$ and $\mathrm{B} 6 \mathrm{C} 3 \mathrm{~F})$ share similar aberrations resulting in copy-number reduction and allelic loss at Ikaros and Bcllb but not at the Cdkn2a/Cdk2b and Pten when compared to their parental strains. Interestingly, Ikaros and $B c l l b$ alterations are due to multilocus deletions, while $C d k n 2 a / C d k 2 b$ and Pten show uniparental disomy. In these specific mice, 
Ikaros appears to be lost first followed by Bcl11l at a later time, in contrast with BALB/c $\times$ MSM hybrids where the order is reversed [132]. Rearrangements within the T-cell receptor alpha, Tcra, are also more common in these $\mathrm{C} 57 \mathrm{BL} / 6$ and $\mathrm{C} 3 \mathrm{H}$ hybrids as compared to those of the T-cell receptor beta, Tcrb, although both aberrations are observed. Allelic loss of Tcrb, a more strictly regulated allele, suggests that increased aberrant $\mathrm{V}(\mathrm{D}) \mathrm{J}$ rearrangement or increases in illegitimate $\mathrm{V}(\mathrm{D}) \mathrm{J}$ recombination might be important in IR-induced lymphomagenesis and may be the basis for strain differences in susceptibility to RI-TL [132]. Deficiencies in V(D)J activity have also been associated with intragenic deletion in BCL11B and Notch1 in human lymphoid malignancies [160-162].

Kominami and Niwa have expanded the idea of an indirect mechanism of RI-TL, where IR may contribute to induction through genomic instability, but does not necessarily target thymocytes for the promotion of TL [163]. Fractionated total body irradiation leads to thymocyte apoptosis and that in turn leads to differentiation arrest and population regeneration by the damaged but surviving thymocytes with tumorigenic potential [124,164-166]. Transplantation or intravenous infusion of unirradiated bone marrow into an irradiated host reduces lymphomagenesis possibly by restoring the thymic microenvironment and preventing clonal expansion of irradiated T-cell precursors. Similarly, bone marrow shielding protects against RI-TL possibly through the same thymus repopulation mechanism. Inversely, transplantation of a non-irradiated thymus into an irradiated animal can develop into full TL [165,167-169]. Additionally, Muto and colleagues demonstrated that intrathymic (i.t.) and intraperitoneal (i.p.) injections of thymocytes from irradiated donors 4 months post-IR into unirradiated hosts results in T-type lymphomas of the donor type. At one month post-IR only intrathymic injections result in donor-type lymphomas in the recipient host suggesting the necessity of the thymus for further promotion in these "prelymphoma cells." Identical experiments but with bone marrow cell injections did not induce lymphomas in recipients indicating that the bone marrow might not be the site of origin of the prelymphoma cells [170]. Furthermore, RF mice subjected to thymectomy prior to irradiation have a reduced incidence of TL down to $1 \%$ from $32 \%$ [29]. Collectively, all of these findings suggest that IR targets additional cells and tissues, not only the thymocytes, at the origin of this malignancy and that the thymic environment plays an important role in TL promotion.

Notch ligands and receptors appear to at least partially mediate the interaction between thymus tissues and hematopoietic progenitors leading to lymphoma [163]. Further contributing to the indirect model of lymphomagenesis might be alterations in regulation of reactive oxygen species (ROS) in surviving thymocytes, leading to the accumulation of ROS-induced mutations [171,172]. Tamura et al. have identified a candidate susceptibility gene $\mathrm{Mtf}-1$ (metal responsive transcription factor-1) and later demonstrated that a certain variant of $M T F-1$, found in susceptible BALB/c mice, is linked to more proliferating premature thymocytes with higher ROS levels than in the strain of mice resistant to RI-TL [173,174]. MTF-1 is activated by heavy metals and is involved in post-radiation signaling pathways regulating intracellular ROS [175].

While thymic lymphoma is a malignancy observed in mice but not in man, radiation-induced lymphomagenesis models can offer important insight into the progression of hematopoietic neoplasias in humans as well. Ikaros, identified in RI-TL mice, has also been implicated in human acute lymphoblastic leukemia (ALL), the most common hematopoietic malignancy among children [144,176-179]. Tsuji et al. demonstrated the contribution of illegitimate V(D)J recombination 
to Notch1 5'-deletions in radiation-induced thymic lymphoma, deregulation of which is thought to be involved in etiology of B- and T-cell human lymphomagenesis [180]. Notch1, a diverse master regulator responsible for a plethora of cellular processes, is itself an important player in both RI-TL and T-cell acute lymphoblastic leukemia [181]. Similarly, PTEN [182] and CDKN2A/CDKN2B have been proposed as candidates for initiation and/or progression of human ALL [183,184]. A new target gene, EPHA7, has been recently uncovered in the RI-TL mouse model and correlated with human T-cell lymphoblastic leukemia/lymphoma (T-LBL). EPHA7 is inactivated in 100\% of T-LBL in mice and $95.23 \%$ of humans by either loss of heterozygocity, promoter hypermethylation or a combination of both [185].

\subsection{Radiation-Induced Lung Cancer}

In most industrialized nations, including the United States, lung carcinoma accounts for about a quarter of all cancer deaths, with the majority of cases being attributable to tobacco smoke [186]. Of the cancers associated with radiation, lung carcinoma was one of the first to be identified due to its high mortality [187]. Historically, data on radiation's contribution to lung carcinogenesis has primarily come from three groups of exposed individuals: (1) underground miners exposed to alpha radiation through radon-222 and radon-220 inhalation, (2) patients treated with IR for neoplastic and non-neoplastic malignacies, (3) and the Japanese atomic bomb survivors [4,188,189]. Minimal latency for gamma and X-ray exposed patients appears to be 9-10 years with a persistent increase in risk remaining over 25 years after exposure. Females tend to be considerably more susceptible to radiation-induced lung cancer than men when researchers have accounted for the confounding factor of smoking. Based on the data from Japanese survivors, adenocarcinoma appears to be the most common type of lung cancer in the exposed population, and no correlation is apparent between age at time of exposure and malignancy risk [4,190,191]. Travis and colleagues have reported a significant increase in all histopathological types of lung cancer in Hodgkin's disease patients treated with radiation up to 40 Gy or more after controlling for smoking. The incidence of secondary lung cancers in Hodgkin's patients peaks at 5-9 years following radiation therapy [192-194]; the reason for this shorter latency remains to be established. Recently, the data set has been complemented by new studies reporting an increase in lung cancer incidence in women treated with radiation for breast cancer $[195,196]$.

In both humans and animals, delayed effects of radiation exposure are pulmonary fibrosis, the replacement of normal tissue with connective tissue fibers, and carcinogenesis. The induction of pulmonary fibrosis versus the induction of lung cancer appears to be a function of dose, with carcinogenesis requiring a much smaller dose [187]. A report by Williams et al. provides an extensive guide to animal model selection for radiation fibrosis in addition to other radiation-induced malignancies [11]. This review summarizes three models of radiation-induced lung cancer employing whole body irradiations and targeted thoracic exposures in $\mathrm{C} 3 \mathrm{H}, \mathrm{BALB} / \mathrm{c}$ and RF mice. Table 4 summarizes the strains and methodologies of induction. 
Table 4. Induction of lung cancer in mice with low-LET ionizing radiation.

\begin{tabular}{|c|c|c|c|c|c|c|c|c|}
\hline Malignancy & Mouse Strain & Age & Sex & $\begin{array}{c}\text { Mode of } \\
\text { Induction }\end{array}$ & Latency & $\begin{array}{c}\text { Spontaneous } \\
\text { Frequency }\end{array}$ & $\begin{array}{c}\text { Induced } \\
\text { Frequency }\end{array}$ & Ref. \\
\hline $\begin{array}{l}\text { Lung } \\
\text { Cancer }\end{array}$ & $\begin{array}{c}\mathrm{C} 3 \mathrm{H} \\
(\mathrm{C} 3 \mathrm{H} / \mathrm{HeSlc})\end{array}$ & $\begin{array}{c}6 \\
\text { weeks }\end{array}$ & Male & $\begin{array}{l}2 \text { fractions of } \\
7.5 \text { Gy to the } \\
\text { thorax } 12 \mathrm{~h} \\
\text { apart }\end{array}$ & $\begin{array}{c}12 \\
\text { months }\end{array}$ & $3.5-9.5 \%$ & $40 \%$ & $\begin{array}{r}{[190,} \\
191]\end{array}$ \\
\hline $\begin{array}{l}\text { Lung } \\
\text { Cancer }\end{array}$ & $\begin{array}{c}\text { RFM } \\
\text { (RFM/Un) }\end{array}$ & $\begin{array}{l}10-12 \\
\text { weeks }\end{array}$ & Female & $\begin{array}{l}9 \text { Gy to } \\
\text { thorax }\end{array}$ & $\begin{array}{c}9 \\
\text { months }\end{array}$ & $\sim 28 \%$ & $87 \%$ & $\begin{array}{l}{[193,} \\
194]\end{array}$ \\
\hline $\begin{array}{l}\text { Lung } \\
\text { Cancer }\end{array}$ & $\begin{array}{c}\mathrm{BALB} / \mathrm{c} \\
(\mathrm{BALB} / \mathrm{c} / \mathrm{An})\end{array}$ & $\begin{array}{c}12 \\
\text { weeks }\end{array}$ & Female & 2 Gy TBI & $\begin{array}{c}12 \\
\text { months }\end{array}$ & $\sim 12 \%$ & $\sim 37 \%$ & $\begin{array}{l}{[195,} \\
196]\end{array}$ \\
\hline
\end{tabular}

\subsubsection{C3H Mouse}

$\mathrm{C} 3 \mathrm{H} / \mathrm{He}$ mice have a low spontaneous frequency of lung tumors and moderate sensitivity to radiation-induced lung tumorigenicity [197]. While the highest frequency of induction at $\sim 62 \%$ is observed with a 7.5 Gy thorax irradiation followed by three 3 Gy whole body irradiations at 3-month intervals, it is potentially irrelevant to lung radiation carcinogenesis in humans. A more clinically relevant scenario is a two-fraction irradiation at 7.5 Gy with a 12-hour interval between the irradiations. This exposure scenario results in a $40 \%$ induction in males irradiated at 6 -weeks of age. After a 12-month latency, treated mice tend to develop alveologenic adenomas and adenocarcinomas; tubular- or papillary-form tumors are rarely observed [198]. In a series of dose-response studies, Hashimoto and colleagues showed that tumor incidence following a single WBI increases up to 5.0 Gy and then begins to decrease, supporting a previously suggested model of competitive dynamics between inductive and suppressive effects of radiation [199].

Night irradiations are much more potent inducers of RI-LT in $\mathrm{C} 3 \mathrm{H}$ mice than exposures during the day. To achieve the same tumor frequency as that seen at night with a 1.25 Gy irradiation a 5 Gy irradiation is required during the day [198]. Diurnal variations have been also reported in responses to cancer therapy in man as well and have been the basis for a clinical study [200]. C3H appears to be the optimal choice for ionizing radiation-induced lung carcinogenesis with its low spontaneous and moderate induction frequencies. Coggle and colleagues suggested that induction with thoracic irradiations is the preferred method [187] because it is clinically more relevant and reduces the incidence of other tumors in the animal that can contribute to lethality.

\subsubsection{RF Mouse}

Lung adenoma is inducible with ionizing radiation in both male and female RFM/Un mice when they are exposed at 10-12-week old [201,202]. Following a single irradiation with 9.0 Gy to the thorax roughly $87 \%$ of female RFM/Un mice develop lung cancer within 6-9 months with an average of 1.8 tumors per mouse. With a dose of 10.0 Gy $54 \%$ of male RFM/Un develop the same malignancy with a tumor multiplicity of 0.8 tumors per mouse within 11 months. However, there is a relatively high incidence of spontaneous lung carcinogenesis, at $28 \%$ in females and $\sim 32 \%$ in males over the course of their lifespan [201,202]. 


\subsubsection{BALB/c Mouse}

A single TBI dose of 2.0 Gy at 12 weeks of age with a high dose rate $(0.35 \mathrm{~Gy} / \mathrm{min})$ administered to a female BALB/c/An mouse, on average, results in a 37\% induction of lung adenocarcinoma. The rate of spontaneous lung adenocarcinoma is between 11-14\% [203]. Fractionation at 2.0 Gy per dose does not increase the incidence of lung carcinoma when compared to a single acute exposure at low dose-rates [204].

\subsubsection{Lung Cancer-Associated Molecular Pathologies}

The effects of the dose, dose-rate, fractionation and radiation quality on lung carcinogenesis in the mouse have been studied extensively, but the underlying molecular pathologies were more difficult to investigate until the recent emergence of genetically engineered mice (GEM). Most molecular pathologies identified in GEM are yet to be correlated with molecular pathologies observed in inbred animals [199,201-205]. Some data have been retroactively extrapolated from radiation studies involving 40,000 B6CF1 hybrid mice (C57BL/6 females $\times$ BALB/c male) conducted at Argonne National Laboratory between 1971 and 1986 [206,207]. Genetic material extracted from lung tissues preserved in paraffin and amplified with PCR from animals with adenocarcinomas and controls revealed that a significant percentage of animals with either radiation-induced or spontaneous lung adenocarcinoma have deletions of $R b$, a tumor suppressor. Zhang and Woloschack reported that $97 \%$ of samples with $R b$ deletions also carried $p 53$ deletions and concluded that $p 53$ mutations may be one of the predominant mutations leading to radiation-induced lung carcinogenesis in B6CF1 mice [207]. Additionally, the same methodology has uncovered a high rate of point mutations in the $K$-ras gene in spontaneous (75\%) irradiation-induced (50\%) mouse lung adenocarcinomas [208].

Salient features of human lung tumors, be they carcinogen-induced or spontaneous, are also shared by murine lung cancers with alterations in $p 53, K$-ras, and $R b$ among others [209-211]. $p 53$ is a tumor suppressor and cell cycle regulator, commonly known as the "guardian of the genome", is either deleted or mutated in $80 \%$ of primary lung tumors [212-215]. Its loss is associated with poor clinical outcome [209]. It is thought that p53 antitumor activity is tightly linked to apoptosis induction [216]. Retinoblastoma protein $(R b)$ and its associated pathway is another tumor suppressor mechanism that is either directly or indirectly inactivated in a variety of tumors, including a $90 \%$ rate in human small cell carcinomas [217,218]. $R b$ in involved in the regulation of cell cycle progression from $\mathrm{G}_{1}$ to $\mathrm{S}$ [219]. Proto-oncogene $K$-ras, involved in cell differentiation, growth, and apoptosis [220], is mutated in $20-30 \%$ of human lung adenocarcinomas [221]. Activated $K$-ras is also associated with poor clinical prognosis [222]. Table 5 summarizes the relevant molecular pathologies linked to IR lung cancer.

The data on the underlying molecular and pathophysiological basis of radiation-induced lung cancer in animal models is rather lacking, but nevertheless, the use of these inbred models can be valuable in testing therapeutic agents against secondary cancers in man. Further research into the mechanisms of induction and promotion of IR-induced lung carcinogenesis in inbred mice has the potential to uncover novel therapeutic targets for preventing secondary neoplastic malignancies in man following radiation therapy. Genetically engineered mice mimicking human cancers, such as K-ras knockout mouse model of lung adenocarcinoma [12], are very useful and sophisticated models but are potentially self-limiting 
and biased. These animals are predisposed to develop only a certain type of malignancy along a designated progression route and do not allow for the study of alternative mechanisms of carcinogenesis. If radiation-induced lung carcinogenesis does not follow the pre-programmed initiation and progression in a certain GEM employed, then the studies using these mice are not of general use and therapies based on these models might not be effective. Using inbred mice, however, may present a more unbiased approach to these "discovery" studies.

Table 5. Molecular pathologies associated with radiation-induced lung cancer.

\begin{tabular}{|c|c|c|c|c|}
\hline $\begin{array}{l}\text { Mouse } \\
\text { Strain }\end{array}$ & Malignancy & Molecular Pathology & Role in Cancer & Ref. \\
\hline \multirow{3}{*}{ B6CF1 } & \multirow{3}{*}{$\begin{array}{c}\text { Lung } \\
\text { Adenocarcinoma }\end{array}$} & $\begin{array}{c}-R b \text { deletions/point } \\
\text { mutations }\end{array}$ & $\begin{array}{l}\text { Tumor suppressor; cell cycle } \\
\text { progression control from } \mathrm{G}_{1} \text { to } \mathrm{S} \\
\text {-Inactivated in } 90 \% \text { small cell } \\
\text { carcinomas }\end{array}$ & $\begin{array}{c}{[207,} \\
217-219]\end{array}$ \\
\hline & & $\begin{array}{c}\text {-p53 deletions/point } \\
\text { mutations }\end{array}$ & $\begin{array}{l}\text { Tumor suppressor; cell cycle regulator } \\
\text { and apoptosis inducer } \\
\text { Deleted or mutated in } 80 \% \text { of primary } \\
\text { lung tumors and other cancers }\end{array}$ & $\begin{array}{c}{[209,} \\
212-216]\end{array}$ \\
\hline & & $\begin{array}{l}\text {-K-ras point } \\
\text { mutations }\end{array}$ & $\begin{array}{l}\text { Proto-oncogene; cell growth and } \\
\text { differentiation } \\
\text { Mutated } R A S \text { found in } 20-30 \% \text { of } \\
\text { lung adenocarcinoma } \\
\end{array}$ & $\begin{array}{c}{[208,} \\
220-222]\end{array}$ \\
\hline
\end{tabular}

\subsection{Radiation-Induced Breast Cancer}

Early compelling data linking radiation and breast cancer have been gathered from the Japanese female survivors of the atomic bomb attacks, females subjected to diagnostic fluoroscopes in Massachusetts tuberculosis sanatoria, and women treated for postpartum mastitis in New York [5]. In fact, in the Japanese atomic bomb survivors breast carcinoma presents the greatest radiation-induced increase in relative risk among all solid tumors [4]. The Massachusetts study demonstrated that females exposed to over a hundred diagnostic X-rays over the years were $80 \%$ more likely to develop breast tumors [223]. More reports are constantly emerging, implicating radiation therapy in secondary breast cancers. All of these studies demonstrate dependency on age during exposure. Up to 35\% of women treated with radiation for Hodgkin's disease at an early age developed breast cancer by the age of forty. Bhatia and Sankila studies approximated secondary radiation-induced breast cancer latency to over 10 years following radiation exposure [224,225]. Stovall and colleagues reported that an absorbed dose of $>1 \mathrm{~Gy}$ to the contralateral breast during radiotherapy is linked to a high risk of secondary de novo contralateral breast cancer (CBC) [226]. Risk for CBC was also linked with the reproductive history of a patient: women who have never given birth or became pregnant after the first diagnosis and subsequent radiation therapy were more likely to develop CBC than matched controls [227].

Ionizing radiation is a well-established etiological agent of both rodent and human breast cancer [190,203,228-233]. Despite the fact that mammary cancer mouse models are somewhat dissimilar from human breast cancers-low frequency of hormonal dependence of the tumor and carcinomas originating in the alveolar tissue-they are nonetheless valuable in studying 
chemotherapeutic preventative and therapeutic agents in addition to modeling the underlying molecular pathology [230]. The BALB/c mouse has been used extensively as a model of mammary cancer either with cancer either being induced with a TBI or through the implantation of irradiated tissues into syngenic mice [234]. Table 6 summarizes the most commonly used BALB/c models.

Table 6. Induction of breast cancer in mice with low-LET ionizing radiation.

\begin{tabular}{|c|c|c|c|c|c|c|c|c|}
\hline Malignancy & $\begin{array}{l}\text { Mouse } \\
\text { Strain }\end{array}$ & Age & Sex & $\begin{array}{c}\text { Mode of } \\
\text { Induction }\end{array}$ & Latency & $\begin{array}{c}\text { Spontaneous } \\
\text { Frequency }\end{array}$ & $\begin{array}{c}\text { Induced } \\
\text { Frequency }\end{array}$ & Ref. \\
\hline $\begin{array}{l}\text { Breast } \\
\text { Cancer }\end{array}$ & BALB/c & $\begin{array}{c}12 \\
\text { weeks }\end{array}$ & Female & $\begin{array}{c}2.0 \mathrm{~Gy} \\
\text { exposure } \\
\text { (TBI) }\end{array}$ & $\begin{array}{c}\sim 24 \\
\text { months }\end{array}$ & $8 \%$ & $22 \%$ & [235] \\
\hline $\begin{array}{l}\text { Breast } \\
\text { Cancer }\end{array}$ & $\begin{array}{c}\text { BALB/c } \\
\text { orthograft }\end{array}$ & $\begin{array}{c}12 \\
\text { weeks }\end{array}$ & Female & $\begin{array}{c}1.0 \mathrm{~Gy} \\
\text { TBI of } \\
\text { donor } \\
\text { cells }\end{array}$ & $\begin{array}{c}10 \\
\text { weeks }\end{array}$ & $<1 \%$ & $\begin{array}{c}* \\
\text { Dysplasia } \\
\sim 75 \% \\
* \text { Tumors } \\
\sim 25 \%\end{array}$ & [236] \\
\hline $\begin{array}{l}\text { Breast } \\
\text { Cancer }\end{array}$ & $\begin{array}{l}\text { BALB/c } \\
\text { chimera }\end{array}$ & $\begin{array}{c}12 \\
\text { weeks }\end{array}$ & Female & $\begin{array}{c}4.0 \mathrm{~Gy} \\
\text { TBI of } \\
\text { host }\end{array}$ & 6 weeks & $\sim 19 \%$ & $\sim 81 \%$ & [237-240] \\
\hline
\end{tabular}

* Dependent on the passage status of the donor cells.

\subsubsection{BALB/c Whole-Body Exposure Model}

Original studies on BALB/c females whole-body irradiated with gamma rays have shown an increase in mammary carcinogenesis, from a background frequency of around $8 \%$ to about $22 \%$ within the mouse's lifetime. To induce mammary adenocarcinoma, BALB/c females are irradiated at 12-weeks of age with a total dose of 2.0 Gy at a relatively high dose-rate of $\sim 0.35 \mathrm{~Gy} / \mathrm{min}$; irradiation with the same total dose but a much smaller dose-rate of $0.083 \mathrm{~Gy} /$ day results in roughly half of the high dose-rate frequency at $\sim 13 \%$ [203]. In fact, even a dose of 0.25 Gy but at the high dose-rate of $0.35 \mathrm{~Gy} / \mathrm{min}$ induces mammary tumors in roughly $20 \%$ of animals [204]. Irradiation does not change latency but rather affects the incidence of breast adenocarcinomas. Prior to the appearance of tumors, hyperplastic lesions in the ductal dysplasia are detected 12-14 months after IR exposure [235]. Sensitivity to radiation-induced breast adenocarcinoma in the BALB/c female has been attributed to polymorphisms of Prkdc, a DNA-dependent protein kinase involved in DNA repair and post-IR cell signaling [241]. This model, however, is plagued by ovarian tumors detected in over $90 \%$ of autopsied mice [203].

\subsubsection{BALB/c Syngenic Transplant Model}

A great leap forward in the field of breast cancer biology was made in 1959 when DeOme and colleagues introduced a murine orthograft model of breast cancer. The model involves clearing of the fat pad in 3-week-old female virgin mice, followed by a transplant of a $1 \mathrm{~mm}$ duct fragment from a donor mouse containing hyperplastic lesions [236,242]. Ethier and Ullrich successfully adapted this model from the original $\mathrm{C} 3 \mathrm{H}$ mice to $\mathrm{BALB} / \mathrm{c}$ and later extensively used it to demonstrate strain 
sensitivity differences and the associated molecular mechanism [236,243-245]. Additionally, Barcellos-Hoff and colleagues employed this model to further revolutionize the cancer research field demonstrating the importance of tissue microenvironment in breast carcinogenesis [237-240].

In the "cell dissociation assay" or the in vitro/in vivo model employed by Ethier and Ullrich, virgin donor BALB/c females are TBI irradiated with a total dose of 1.0 Gy at 12-weeks of age, then their mammary tissues are removed at 24 hours post-exposure. Single-cell suspensions of $10^{4}$ cells, prepared from these donor animals, are then injected into 3-week-old virgin BALB/c females whose mammary fat pad had been removed. At 10 weeks following the procedure, the mice are sacrificed and the outgrowths are removed and analyzed for pathologies in the ductal architecture. Normal outgrowths have 2-3 terminal ducts that are capped by end buds in the fat pad and resemble anatomically correct ducts. Abnormal outgrowths have up to 10 or more terminal ducts capped with hyperplastic end buds are and assigned an arbitrary classification I-III, with Class III being the most severe [244,246,247].

In a series of elegant experiments, Ullrich and colleagues demonstrated thaT cells from the irradiated donor harvested at different time points after irradiation, passaged in vitro, and transplanted into unirradiated recipient mice develop either dysplasia or adenocarcinomas depending on the time of harvesting or the number on passages in culture prior to implantation. Cells harvested at 52 weeks post-IR and injected into recipient host tend to regenerate dysplastic outgrowths at a high rate (3 in 4) and develop into tumors ( 1 in 4) while cells harvested at 1-16 weeks develop into normal outgrowths unless they have undergone extensive in vitro passaging. Dysplasia and tumors resembled in situ tumorigenesis with leukocyte infiltrations and angiogenesis [235].

Barcellos-Hoff and Ravi capitalized on this model and have established a radiation chimera model of their own [248] in which the fat pads of BALB/c mouse hosts are cleared at 3-weeks of age and the mice themselves are TBI irradiated with 4.0 Gy at 10-12-weeks of age. Three days later these hosts are subsequently transplanted with immortalized but non-malignant, unirradiated COMMA-D mouse epithelial cells from midpregnant BALB/c females [249]. At 6 weeks post-IR, the cells injected into irradiated host have $81 \%$ tumor penetrance as compared to $19 \%$ in the unirradiated host. Alternatively, a $1 \mathrm{~mm}^{3}$ fragment of the formed epithelia from a wildtype donor or a donor primed for neoplastic development can be transplanted into the irradiated host whose mammary fat pads have been cleared [250]. This syngenic mode demonstrates that radiation-induced changes in the stromal microenvironment contribute to carcinogenicity [248].

\subsubsection{Breast Cancer-Associated Molecular Pathologies}

Cell lines established from female BALB/c donors irradiated with 1.0 Gy and harvested at 4 weeks (EF42) or 16 weeks (EF137) were used in early studies to examine molecular pathologies leading to tumorigenesis. Reduced or absent $R b$ protein was detected in EF42 after 11 passages and in EF137 after only 6 passages in culture. Mutant p53 was detected in $95 \%$ after $>20$ passage and $1-5 \%$ in passages $6-10$ suggesting that it is an early transformation event in preneoplastic cells. Additionally, following 20 passages in culture angiogenesis is often detected [235]. Ethier and Ullrich reported that injecting a larger number of cells results in a less frequent and less pronounced dysplasia as compared to an injection with fewer cells [244,246]. This observation suggests that replicative stress might be contributing to a faster and more prominent progression to ductal dysplasia as in the case with TL. 
Barcellos-Hoff and colleagues have linked rapid remodeling of the microenvironment observed in the irradiated mammary gland to changes in the extracellular matrix and latent Transforming Growth Factor Beta (TGF- $\beta$ ) expression [237,251-253] and later showed that it accelerates tumor progression [250]. TGF- $\beta$ is involved in regulating a variety of cell processes including cell cycle control, apoptosis and cell differentiation among others [252,254]. Radiation-induced activation of TGF- $\beta$ has been additionally implicated in cell fate decisions and influence DNA-repair kinetics in an ATM-dependent manner [255,256].

The radiation chimera model is able to capture salient features of breast cancer that are thought to arise after irradiation, despite the fact that, unlike in the case of human malignancy, the transplanted epithelium itself has not been irradiated. Human breast cancer associated with radiation exposure has been shown to initiate in the ducT cells that often infiltrate the rest of the breast tissue [5] similarly to the way mammary cancer arises in the transplantation models. Barcellos-Hoff and colleagues have also reported that tumors arising from transplanted epithelium lack functional $p 53$ protein and are estrogen receptor (ER) negative [250], akin to those observed in women with breast cancer who have been previously irradiated [257]. $R b$ deficiencies observed by Ullrich and Preston in neoplastic ducT cells have also been reported in human breast cancer tumors and correlated with a highly invasive tumor phenotype [258]. Table 7 summarizes relevant molecular pathologies in radiation-induced breast cancer studies.

Table 7. Molecular pathologies associated with radiation-induced breast cancer.

\begin{tabular}{|c|c|c|c|c|}
\hline $\begin{array}{l}\text { Mouse } \\
\text { Strain }\end{array}$ & Malignancy & $\begin{array}{l}\text { Molecular } \\
\text { Pathology }\end{array}$ & Role in Cancer & Ref. \\
\hline \multirow{3}{*}{$\mathrm{BALB} / \mathrm{c}$} & \multirow{3}{*}{$\begin{array}{c}\text { Mammary } \\
\text { Adenocarcinoma }\end{array}$} & $\begin{array}{l}\text { - Reduction or } \\
\text { loss of } R b\end{array}$ & $\begin{array}{l}\text { Tumor suppressor; cell cycle } \\
\text { progression control from } \mathrm{G}_{1} \text { to } \mathrm{S} \\
\text { Inactivated in } 90 \% \text { small cell } \\
\text { carcinomas }\end{array}$ & {$[235,258]$} \\
\hline & & -p53 mutation & $\begin{array}{l}\text { Tumor suppressor; cell cycle } \\
\text { regulator and apoptosis inducer } \\
\text { Among the key mutations in breast } \\
\text { cancer initiation }\end{array}$ & $\begin{array}{c}{[235,250,} \\
257]\end{array}$ \\
\hline & & $\begin{array}{l}\text {-TGF- } \beta \\
\text { expression }\end{array}$ & $\begin{array}{l}\text { Cell cycle control; apoptosis; cell } \\
\text { differentiation } \\
\text { Linked to pro-tumorigenic } \\
\text { microenvironment }\end{array}$ & $\begin{array}{c}{[245,} \\
251-256]\end{array}$ \\
\hline
\end{tabular}

\section{Conclusions}

An ideal mouse model of radiation-induced carcinogenesis would have a low spontaneous background frequency of the desired malignancy, would not co-develop cancers at alternative sites, would have a short latency period and would have tumors that are nearly identical to corresponding human disease in their onset, progression and underlying pathology. Such a perfect model, however, does not exist and we are therefore forced to compromise on some of these features. While we can, perhaps, compromise on the latency of the cancers and the frequencies of inductions, we cannot afford to compromise on the molecular and pathophysiological similarities to human radiation-induced 
malignancies that these models must mimic. Much work in the field of radiation oncology remains to be done in order to develop more accurate recapitulations of human radiation-induced cancers. Today we are still at the stage where we still have difficulty discerning radiation-induced secondary cancers from primary tumors in men because the molecular signatures of each type remain to be established. Relating these molecular signatures to tumors that arise in mice following IR is yet another degree of difficulty.

Murine models presented within the scope of this review are most often a compromise on background frequencies and rates of induction, but they do demonstrate strong molecular and phenotypic correlations to salient features of the human cancers they are meant to represent. This enables these models to be rightfully employed to test the extent of therapeutic benefits of candidate drugs against radiation-induced carcinogenesis.

\section{References}

1. Seer Cancer Statistics Review, 1975-2009 (Vintage 2009 Populations); Howlader, N., Noone, A.M., Krapcho, M., Neyman, N., Aminou, R., Altekruse, S.F., Kosary, C.L., Ruhl, J., Tatalovich, Z., Cho, H., Mariotto, A., Eisner, M.P., Lewis, D.R., Chen, H.S., Feuer, E.J., Cronin, K.A., Eds.; National Cancer Institute: Bethesda, MD, USA, 2012.

2. Ringborg, U.; Bergqvist, D.; Brorsson, B.; Cavallin-Stahl, E.; Ceberg, J.; Einhorn, N.; Frodin, J.E.; Jarhult, J.; Lamnevik, G.; Lindholm, C.; et al. The swedish council on technology assessment in health care (SBU) systematic overview of radiotherapy for cancer including a prospective survey of radiotherapy practice in sweden 2001-Summary and conclusions. Acta oncologica 2003, 42, 357-365.

3. Prasanna, P.G.; Stone, H.B.; Wong, R.S.; Capala, J.; Bernhard, E.J.; Vikram, B.; Coleman, C.N. Normal tissue protection for improving radiotherapy: Where are the gaps? Transl. Cancer Res. 2012, 1, 35-48.

4. Fajardo, L.F.; Berthrong, M.; Anderson, R.E. Radiation Pathology; Oxford University Press: New York, 2001; p. 454.

5. Hall, E.J.; Giaccia, A.J. Radiobiology for the Radiologist, 7th ed.; Wolters Kluwer Health/Lippincott Williams \& Wilkins: Philadelphia, PA, USA, 2012.

6. Zelefsky, M.J.; Fuks, Z.; Leibel, S.A. Intensity-modulated radiation therapy for prostate cancer. Semin. Radiat. Oncol. 2002, 12, 229-237.

7. de Arruda, F.F.; Puri, D.R.; Zhung, J.; Narayana, A.; Wolden, S.; Hunt, M.; Stambuk, H.; Pfister, D.; Kraus, D.; Shaha, A.; et al. Intensity-modulated radiation therapy for the treatment of oropharyngeal carcinoma: The memorial sloan-kettering cancer center experience. Int J. Radiat. Oncol. Biol. Phys. 2006, 64, 363-373.

8. Kim, K.; Damoiseaux, R.; Norris, A.J.; Rivina, L.; Bradley, K.; Jung, M.E.; Gatti, R.A.; Schiestl, R.H.; McBride, W.H. High throughput screening of small molecule libraries for modifiers of radiation responses. Int. J. Radiat. Biol. 2011, 87, 839-845.

9. Rubin, P. Cured I-Lent: Late Effects of Cancer Treatment on Normal Tissues (Medical Radiology/Radiation Oncology); Springer: Berlin, Germany, 2008; p. 140. 
10. Ryan, J.L.; Krishnan, S.; Movsas, B.; Coleman, C.N.; Vikram, B.; Yoo, S.S. Decreasing the adverse effects of cancer therapy: An NCI workshop on the preclinical development of radiation injury mitigators/protectors. Radiat. Res. 2011, 176, 688-691.

11. Williams, J.P.; Brown, S.L.; Georges, G.E.; Hauer-Jensen, M.; Hill, R.P.; Huser, A.K.; Kirsch, D.G.; Macvittie, T.J.; Mason, K.A.; Medhora, M.M.; et al. Animal models for medical countermeasures to radiation exposure. Radiat. Res. 2010, 173, 557-578.

12. Jackson, E.L.; Willis, N.; Mercer, K.; Bronson, R.T.; Crowley, D.; Montoya, R.; Jacks, T.; Tuveson, D.A. Analysis of lung tumor initiation and progression using conditional expression of oncogenic K-ras. Gene. Develop. 2001, 15, 3243-3248.

13. Frese, K.K.; Tuveson, D.A. Maximizing mouse cancer models. Nat. Rev. Cancer 2007, 7, 645-658.

14. Hall, E.J.; Giaccia, A.J. Radiobiology for the Radiologist, 6th ed.; Lippincott Williams \& Wilkins: Philadelphia, PA, USA, 2006; p. 546.

15. Little, M.P.; Weiss, H.A.; Boice, J.D., Jr.; Darby, S.C.; Day, N.E.; Muirhead, C.R. Risks of leukemia in japanese atomic bomb survivors, in women treated for cervical cancer, and in patients treated for ankylosing spondylitis. Radiat. Res. 1999, 152, 280-292.

16. Preston, D.L.; Kusumi, S.; Tomonaga, M.; Izumi, S.; Ron, E.; Kuramoto, A.; Kamada, N.; Dohy, H.; Matsuo, T.; Matsui, T.; et al. Cancer incidence in atomic bomb survivors. Part III. Leukemia, lymphoma and multiple myeloma, 1950-1987. Radiat. Res. 1994, 137, S68-S97.

17. Weiss, H.A.; Darby, S.C.; Doll, R. Cancer mortality following X-ray treatment for ankylosing spondylitis. Int. J. Cancer 1994, 59, 327-338.

18. Weiss, H.A.; Darby, S.C.; Fearn, T.; Doll, R. Leukemia mortality after X-ray treatment for ankylosing spondylitis. Radiat. Res. 1995, 142, 1-11.

19. Wakeford, R.; Kendall, G.M.; Little, M.P. The proportion of childhood leukaemia incidence in great britain that may be caused by natural background ionizing radiation. Leukemia 2009, 23, 770-776.

20. Boice, J.D., Jr.; Engholm, G.; Kleinerman, R.A.; Blettner, M.; Stovall, M.; Lisco, H.; Moloney, W.C.; Austin, D.F.; Bosch, A.; Cookfair, D.L.; et al. Radiation dose and second cancer risk in patients treated for cancer of the cervix. Radiat. Res. 1988, 116, 3-55.

21. Noshchenko, A.G.; Bondar, O.Y.; Drozdova, V.D. Radiation-induced leukemia among children aged 0-5 years at the time of the chernobyl accident. Int. J. Cancer 2010, 127, 412-426.

22. Ivanov, V.K.; Tsyb, A.F.; Gorsky, A.I.; Maksyutov, M.A.; Rastopchin, E.M.; Konogorov, A.P.; Korelo, A.M.; Biryukov, A.P.; Matyash, V.A. Leukaemia and thyroid cancer in emergency workers of the chernobyl accident: Estimation of radiation risks (1986-1995). Radiat. Environ. Biophys. 1997, 36, 9-16.

23. Ivanov, V.K.; Gorskii, A.I.; Tsyb, A.F.; Khaut, S.E. Incidence of post-chernobyl leukemia and thyroid cancer in children and adolescents in the briansk region: Evaluation of radiation risks. Vopr. Onkol. 2003, 49, 445-449.

24. Ivanov, V.K.; Gorski, A.I.; Maksioutov, M.A.; Vlasov, O.K.; Godko, A.M.; Tsyb, A.F.; Tirmarche, M.; Valenty, M.; Verger, P. Thyroid cancer incidence among adolescents and adults in the bryansk region of russia following the chernobyl accident. Health Phys. 2003, 84, 46-60. 
25. Preston, D.L.; Pierce, D.A.; Shimizu, Y.; Cullings, H.M.; Fujita, S.; Funamoto, S.; Kodama, K. Effect of recent changes in atomic bomb survivor dosimetry on cancer mortality risk estimates. Radiat. Res. 2004, 162, 377-389.

26. Little, M.P.; Wakeford, R.; Tawn, E.J.; Bouffler, S.D.; Berrington de Gonzalez, A. Risks associated with low doses and low dose rates of ionizing radiation: Why linearity may be (almost) the best we can do. Radiology 2009, 251, 6-12.

27. Tomonaga, M. Leukaemia in nagasaki atomic bomb survivors from 1945 through 1959. Bull. WHO 1962, 26, 619-631.

28. Little, M.P.; Wakeford, R.; Kendall, G.M. Updated estimates of the proportion of childhood leukaemia incidence in great britain that may be caused by natural background ionising radiation. J. Radiol. Prot. 2009, 29, 467-482.

29. Upton, A.C.; Wolff, F.F.; Furth, J.; Kimball, A.W. A comparison of the induction of myeloid and lymphoid leukemias in X-radiated RF mice. Cancer Res. 1958, 18, 842-848.

30. Wolman, S.R.; McMorrow, L.E.; Cohen, M.W. Animal model of human disease: Myelogenous leukemia in the RF mouse. Am. J. Pathol. 1982, 107, 280-284.

31. Resnitzky, P.; Estrov, Z.; Haran-Ghera, N. High incidence of acute myeloid leukemia in SJL/J mice after X-irradiation and corticosteroids. Leuk. Res. 1985, 9, 1519-1528.

32. Major, I.R.; Mole, R.H. Myeloid leukaemia in X-ray irradiated CBA mice. Nature 1978, 272, 455-456.

33. Major, I.R. Induction of myeloid leukaemia by whole-body single exposure of CBA male mice to X-rays. Brit. J. Cancer 1979, 40, 903-913.

34. Seki, M.; Yoshida, K.; Nishimura, M.; Nemoto, K. Radiation-induced myeloid leukemia in $\mathrm{C} 3 \mathrm{H} / \mathrm{He}$ mice and the effect of prednisolone acetate on leukemogenesis. Radiat. Res. 1991, 127, $146-149$.

35. Chia, R.; Achilli, F.; Festing, M.F.; Fisher, E.M. The origins and uses of mouse outbred stocks. Nat. Genet. 2005, 37, 1181-1186.

36. Festing, M.F. 25 Inbred Strains of Mice as Possible Candidates for a Multi-Strain Carcinogenesis Bioassay. 2005. Available online: http://ntp.niehs.nih.gov/files/MouseStrains_Festing.pdf (accessd on 15 August 2012).

37. Ullrich, R.L.; Preston, R.J. Myeloid leukemia in male RFM mice following irradiation with fission spectrum neutrons or gamma rays. Radiat. Res. 1987, 109, 165-170.

38. Furth, J. Recent experimental studies on leukemia. Physiol. Rev. 1946, 26, 47-76.

39. Cole, R.K.; Furth, J. Experimental studies on the genetics of spontaneous leukamia in mice. Cancer Res. 1941, 1, 957-965.

40. Upton, A.C.; Jenkins, V.K.; Conklin, J.W. Myeloid leukemia in the mouse. Ann. N. Y. Acad. Sci. 1964, 114, 189-202.

41. Upton, A.C.; Buffett, R.F.; Furth, J.; Doherty, D.G. Radiation-induced dental death in mice. Radiat. Res. 1958, 8, 475-479.

42. Azumi, J.I.; Sachs, L. Chromosome mapping of the genes that control differentiation and malignancy in myeloid leukemic cells. Proc. Natl. Acad. Sci. USA 1977, 74, 253-257. 
43. Hayata, I.; Ishihara, T.; Hirashima, K.; Sado, T.; Yamagiwa, J. Partial deletion of chromosome No. 2 in myelocytic leukemias of irradiated C3H/He and RFM mice. J. Nat. Cancer Inst. 1979, 63, 843-848.

44. Morgan, C. Hiroshima, nagasaki and the RERF. Am. J. Pathol. 1980, 98, 843-856.

45. Haran-Ghera, N.; Ben-Yaakov, M.; Peled, A.; Bentwich, Z. Immune status of SJL-J mice in relation to age and spontaneous tumor development. J. Nat. Cancer Inst. 1973, 50, 1127-1135.

46. Dunn, T.B. Normal and pathologic anatomy of the reticular tissue in laboratory mice, with a classification and discussion of neoplasms. J. Nat. Cancer Inst. 1954, 14, 1281-1433.

47. Haran-Ghera, N.; Kotler, M.; Meshorer, A. Studies on leukemia development in the SJL/J strain of mice. J. Nat. Cancer Inst. 1967, 39, 653-661.

48. Haran-Ghera, N.; Krautghamer, R.; Lapidot, T.; Peled, A.; Dominguez, M.G.; Stanley, E.R. Increased circulating colony-stimulating factor-1 (CSF-1) in SJL/J mice with radiation-induced acute myeloid leukemia (AML) is associated with autocrine regulation of AML cells by CSF-1. Blood 1997, 89, 2537-2545.

49. Haran-Ghera, N.; Resnitzky, P.; Krautghamer, R.; Tartakovsky, B. Multiphase process involved in radiation induced murine AML. Leukemia 1992, 6, 123S-125S.

50. Haran-Ghera, N.; Trakhtenbrot, L.; Resnitzky, P.; Peled, A. Preleukemia in experimental leukemogenesis. Haematol. Blood Trans. 1989, 32, 243-249.

51. Trakhtenbrot, L.; Krauthgamer, R.; Resnitzky, P.; Haran-Ghera, N. Deletion of chromosome 2 is an early event in the development of radiation-induced myeloid leukemia in $\mathrm{SJL} / \mathrm{J}$ mice. Leukemia 1988, 2, 545-550.

52. Tartakovsky, B.; Goldstein, O.; Krautghamer, R.; Haran-Ghera, N. Low doses of radiation induce systemic production of cytokines: Possible contribution to leukemogenesis. Int. J. Cancer 1993, 55, 269-274.

53. Cadman, E.C.; Capizzi, R.L.; Bertino, J.R. Acute nonlymphocytic leukemia: A delayed complication of hodgkin's disease therapy: Analysis of 109 cases. Cancer 1977, 40, 1280-1296.

54. Coleman, C.N.; Williams, C.J.; Flint, A.; Glatstein, E.J.; Rosenberg, S.A.; Kaplan, H.S. Hematologic neoplasia in patients treated for hodgkin's disease. N. Engl. J. Med. 1977, 297, 1249-1252.

55. Pedersen-Bjergaard, J.; Philip, P.; Pedersen, N.T.; Hou-Jensen, K.; Svejgaard, A.; Jensen, G.; Nissen, N.I. Acute nonlymphocytic leukemia, preleukemia, and acute myeloproliferative syndrome secondary to treatment of other malignant diseases. II. Bone marrow cytology, cytogenetics, results of hla typing, response to antileukemic chemotherapy, and survival in a total series of 55 patients. Cancer 1984, 54, 452-462.

56. Scholl, S.M.; Bascou, C.H.; Mosseri, V.; Olivares, R.; Magdelenat, H.; Dorval, T.; Palangie, T.; Validire, P.; Pouillart, P.; Stanley, E.R. Circulating levels of colony-stimulating factor 1 as a prognostic indicator in 82 patients with epithelial ovarian cancer. Brit. J. Cancer 1994, 69, 342346.

57. Hakala, A.; Kacinski, B.M.; Stanley, E.R.; Kohorn, E.; Puistola, U.; Risteli, J.; Risteli, L.; Thomas, C.; Kaupillaa, A. Macrophage colony stimulating factor (CSF-1), a clinically usefully tumor arker in endometrial adenocarcinoma: Comparison with CA125 and aminoterminal of type III procollagen. Amer. J. Obstet. Gynecol. 1994, 173, 112-119. 
58. Scholl, S.M.; Lidereau, R.; de la Rochefordiere, A.; Le-Nir, C.C.; Mosseri, V.; Nogues, C.; Pouillart, P.; Stanley, F.R. Circulating levels of the macrophage colony stimulating factor CSF-1 in primary and metastatic breast cancer patients. A pilot study. Breast Cancer Res. Treat. 1996, 39, 275-283.

59. Toy, E.P.; Chambers, J.T.; Kacinski, B.M.; Flick, M.B.; Chambers, S.K. The activated macrophage colony-stimulating factor (CSF-1) receptor as a predictor of poor outcome in advanced epithelial ovarian carcinoma. Gynecol. Oncol. 2001, 80, 194-200.

60. Festing, M.F.; Blackmore, D.K. Life span of specified-pathogen-free (MRC category 4) mice and rats. Lab. Animals 1971, 5, 179-192.

61. Yoshida, K.; Inoue, T.; Nojima, K.; Hirabayashi, Y.; Sado, T. Calorie restriction reduces the incidence of myeloid leukemia induced by a single whole-body radiation in $\mathrm{C} 3 \mathrm{H} / \mathrm{He}$ mice. Proc. Natl. Acad. Sci. USA 1997, 94, 2615-2619.

62. Yoshida, K.; Hirabayashi, Y.; Watanabe, F.; Sado, T.; Inoue, T. Caloric restriction prevents radiation-induced myeloid leukemia in $\mathrm{C} 3 \mathrm{H} / \mathrm{HeMs}$ mice and inversely increases incidence of tumor-free death: Implications in changes in number of hemopoietic progenitor cells. Exp. Hematol. 2006, 34, 274-283.

63. Yoshida, K.; Nemoto, K.; Nishimura, M.; Seki, M. Exacerbating factors of radiation-induced myeloid leukemogenesis. Leuk. Res. 1993, 17, 437-440.

64. Hayata, I.; Seki, M.; Yoshida, K.; Hirashima, K.; Sado, T.; Yamagiwa, J.; Ishihara, T. Chromosomal aberrations observed in 52 mouse myeloid leukemias. Cancer Res. 1983, 43, 367-373.

65. Ban, N.; Kai, M.; Kusama, T. Chromosome aberrations in bone marrow cells of C3H/He mice at an early stage after whole-body irradiation. J. Radiat. Res. 1997, 38, 219-231.

66. Coupland, L.A.; Jammu, V.; Pidcock, M.E. Partial deletion of chromosome 1 in a case of acute myelocytic leukemia. Cancer Genet. Cytogenet. 2002, 139, 60-62.

67. Finger, L.R.; Kagan, J.; Christopher, G.; Kurtzberg, J.; Hershfield, M.S.; Nowell, P.C.; Croce, C.M. Involvement of the TCL5 gene on human chromosome 1 in T-cell leukemia and melanoma. Proc. Natl. Acad. Sci. USA 1989, 86, 5039-5043.

68. Rithidech, K.N.; Cronkite, E.P.; Bond, V.P. Advantages of the CBA mouse in leukemogenesis research. Blood Cells Mol. Dis. 1999, 25, 38-45.

69. Rithidech, K.; Dunn, J.J.; Bond, V.P.; Gordon, C.R.; Cronkite, E.P. Characterization of genetic instability in radiation- and benzene-induced murine acute leukemia. Mutat. Res. 1999, 428, 33-39.

70. Mole, R.H.; Major, I.R. Myeloid leukaemia frequency after protracted exposure to ionizing radiation: Experimental confirmation of the flat dose-response found in ankylosing spondylitis after a single treatment course with X-rays. Leuk. Res. 1983, 7, 295-300.

71. Smith, I.E.; Powles, R.; Clink, H.M.; Jameson, B.; Kay, H.E.; McElwain, T.J. Early deaths in acute myelogenous leukemia. Cancer 1977, 39, 1710-1714.

72. Rithidech, K.N.; Bond, V.P.; Cronkite, E.P.; Thompson, M.H. A specific chromosomal deletion in murine leukemic cells induced by radiation with different qualities. Exp. Hematol. 1993, 21, 427-431.

73. Rithidech, K.; Dunn, J.J.; Roe, B.A.; Gordon, C.R.; Cronkite, E.P. Evidence for two commonly deleted regions on mouse chromosome 2 in gamma ray-induced acute myeloid leukemic cells. Exp. Hematol. 2002, 30, 564-570. 
74. Rithidech, K.; Bond, V.P.; Cronkite, E.P.; Thompson, M.H.; Bullis, J.E. Hypermutability of mouse chromosome 2 during the development of X-ray-induced murine myeloid leukemia. Proc. Natl. Acad. Sci. USA 1995, 92, 1152-1156.

75. Bouffler, S.D.; Meijne, E.I.; Morris, D.J.; Papworth, D. Chromosome 2 hypersensitivity and clonal development in murine radiation acute myeloid leukaemia. Int. J. Radiat. Biol. 1997, 72, 181-189.

76. Cleary, H.; Boulton, E.; Plumb, M. Allelic loss on chromosome 4 (Lyr2/TLSR5) is associated with myeloid, B-lympho-myeloid, and lymphoid (B and T) mouse radiation-induced leukemias. Blood 2001, 98, 1549-1554.

77. Giotopoulos, G.; McCormick, C.; Cole, C.; Zanker, A.; Jawad, M.; Brown, R.; Plumb, M. DNA methylation during mouse hemopoietic differentiation and radiation-induced leukemia. Exp. Hematol. 2006, 34, 1462-1470.

78. Jawad, M.; Giotopoulos, G.; Fitch, S.; Cole, C.; Plumb, M.; Talbot, C.J. Mouse bone marrow and peripheral blood erythroid cell counts are regulated by different autosomal genetic loci. Blood Cells Mol. Dis. 2007, 38, 69-77.

79. Dekkers, F.; Bijwaard, H.; Bouffler, S.; Ellender, M.; Huiskamp, R.; Kowalczuk, C.; Meijne, E.; Sutmuller, M. A two-mutation model of radiation-induced acute myeloid leukemia using historical mouse data. Radiat. Environ. Biophys. 2011, 50, 37-45.

80. Alexander, B.J.; Rasko, J.E.; Morahan, G.; Cook, W.D. Gene deletion explains both in vivo and in vitro generated chromosome 2 aberrations associated with murine myeloid leukemia. Leukemia 1995, 9, 2009-2015.

81. Cook, W.D.; McCaw, B.J.; Herring, C.; John, D.L.; Foote, S.J.; Nutt, S.L.; Adams, J.M. PU.1 is a suppressor of myeloid leukemia, inactivated in mice by gene deletion and mutation of its DNA binding domain. Blood 2004, 104, 3437-3444.

82. Silver, A.; Moody, J.; Dunford, R.; Clark, D.; Ganz, S.; Bulman, R.; Bouffler, S.; Finnon, P.; Meijne, E.; Huiskamp, R.; et al. Molecular mapping of chromosome 2 deletions in murine radiation-induced aml localizes a putative tumor suppressor gene to a $1.0 \mathrm{~cm}$ region homologous to human chromosome segment 11p11-12. Genes Chromosomes Cancer 1999, 24, 95-104.

83. Moreau-Gachelin, F.; Tavitian, A.; Tambourin, P. Spi-1 is a putative oncogene in virally induced murine erythroleukaemias. Nature 1988, 331, 277-280.

84. Scott, E.W.; Simon, M.C.; Anastasi, J.; Singh, H. Requirement of transcription factor PU.1 in the development of multiple hematopoietic lineages. Science 1994, 265, 1573-1577.

85. Simon, M.C.; Olson, M.; Scott, E.; Hack, A.; Su, G.; Singh, H. Terminal myeloid gene expression and differentiation requires the transcription factor PU.1. Curr. Topics Microbiol. Immunol. 1996, 211, 113-119.

86. McKercher, S.R.; Torbett, B.E.; Anderson, K.L.; Henkel, G.W.; Vestal, D.J.; Baribault, H.; Klemsz, M.; Feeney, A.J.; Wu, G.E.; Paige, C.J.; et al. Targeted disruption of the PU.1 gene results in multiple hematopoietic abnormalities. EMBO J. 1996, 15, 5647-5658.

87. Kastner, P.; Chan, S. PU.1: A crucial and versatile player in hematopoiesis and leukemia. Int. J. Biochem. Cell. Biol. 2008, 40, 22-27. 
88. Suraweera, N.; Meijne, E.; Moody, J.; Carvajal-Carmona, L.G.; Yoshida, K.; Pollard, P.; Fitzgibbon, J.; Riches, A.; van Laar, T.; Huiskamp, R.; et al. Mutations of the PU.1 Ets domain are specifically associated with murine radiation-induced, but not human therapy-related, acute myeloid leukaemia. Oncogene 2005, 24, 3678-3683.

89. Mueller, B.U.; Pabst, T.; Osato, M.; Asou, N.; Johansen, L.M.; Minden, M.D.; Behre, G.; Hiddemann, W.; Ito, Y.; Tenen, D.G. Heterozygous PU.1 mutations are associated with acute myeloid leukemia. Blood 2002, 100, 998-1007.

90. Joo, M.; Park, G.Y.; Wright, J.G.; Blackwell, T.S.; Atchison, M.L.; Christman, J.W. Transcriptional regulation of the cyclooxygenase-2 gene in macrophages by PU.1. J. Biol. Chem. 2004, 279, 6658-6665.

91. Rosenbauer, F.; Wagner, K.; Kutok, J.L.; Iwasaki, H.; le Beau, M.M.; Okuno, Y.; Akashi, K.; Fiering, S.; Tenen, D.G. Acute myeloid leukemia induced by graded reduction of a lineage-specific transcription factor, PU.1. Nat. Genet. 2004, 36, 624-630.

92. Metcalf, D.; Dakic, A.; Mifsud, S.; di Rago, L.; Wu, L.; Nutt, S. Inactivation of PU.1 in adult mice leads to the development of myeloid leukemia. Proc. Natl. Acad. Sci. USA 2006, 103, $1486-1491$.

93. Walter, M.J.; Park, J.S.; Ries, R.E.; Lau, S.K.; McLellan, M.; Jaeger, S.; Wilson, R.K.; Mardis, E.R.; Ley, T.J. Reduced PU.1 expression causes myeloid progenitor expansion and increased leukemia penetrance in mice expressing PML-RAR $\alpha$. Proc. Natl. Acad. Sci. USA 2005, 102, 12513-12518.

94. Hirouchi, T.; Takabatake, T.; Yoshida, K.; Nitta, Y.; Nakamura, M.; Tanaka, S.; Ichinohe, K.; Oghiso, Y.; Tanaka, K. Upregulation of $c-M y c$ gene accompanied by PU.1 deficiency in radiation-induced acute myeloid leukemia in mice. Exp. Hematol. 2008, 36, 871-885.

95. Peng, Y.; Brown, N.; Finnon, R.; Warner, C.L.; Liu, X.; Genik, P.C.; Callan, M.A.; Ray, F.A.; Borak, T.B.; Badie, C.; et al. Radiation leukemogenesis in mice: Loss of PU.1 on chromosome 2 in CBA and C57BL/6 mice after irradiation with $1 \mathrm{GeV} /$ nucleon $56 \mathrm{Fe}$ ions, $\mathrm{X}$ rays or gamma rays. Part I. Experimental observations. Radiat. Res. 2009, 171, 474-483.

96. Steidl, U.; Rosenbauer, F.; Verhaak, R.G.; Gu, X.; Ebralidze, A.; Otu, H.H.; Klippel, S.; Steidl, C.; Bruns, I.; Costa, D.B.; et al. Essential role of jun family transcription factors in PU.1 knockdown-induced leukemic stem cells. Nat. Genet. 2006, 38, 1269-1277.

97. Finnon, R.; Brown, N.; Moody, J.; Badie, C.; Olme, C.H.; Huiskamp, R.; Meijne, E.; Sutmuller, M.; Rosemann, M.; Bouffler, S.D. Flt3-ITD mutations in a mouse model of radiation-induced acute myeloid leukaemia. Leukemia 2012, 26, 1445-1446.

98. Plumb, M.; Cleary, H.; Wright, E. Genetic instability in radiation-induced leukaemias: Mouse models. Int. J. Radiat. Biol. 1998, 74, 711-720.

99. Boulton, E.; Cleary, H.; Papworth, D.; Plumb, M. Susceptibility to radiation-induced leukaemia/lymphoma is genetically separable from sensitivity to radiation-induced genomic instability. Int. J. Radiat. Biol. 2001, 77, 21-29.

100. Morgan, W.F. Is there a common mechanism underlying genomic instability, bystander effects and other nontargeted effects of exposure to ionizing radiation? Oncogene 2003, 22, 7094-7099.

101. Busuttil, R.A.; Rubio, M.; Dolle, M.E.; Campisi, J.; Vijg, J. Oxygen accelerates the accumulation of mutations during the senescence and immortalization of murine cells in culture. Aging Cell 2003, 2, 287-294. 
102. Ban, N.; Kai, M. Implication of replicative stress-related stem cell ageing in radiation-induced murine leukaemia. Brit. J. Cancer 2009, 101, 363-371.

103. Hirouchi, T.; Akabane, M.; Tanaka, S.; Braga-Tanaka, I., 3rd; Todate, A.; Ichinohe, K.; Oghiso, Y.; Tanaka, K. Cell surface marker phenotypes and gene expression profiles of murine radiation-induced acute myeloid leukemia stem cells are similar to those of common myeloid progenitors. Radiat. Res. 2011, 176, 311-322.

104. Darakhshan, F.; Badie, C.; Moody, J.; Coster, M.; Finnon, R.; Finnon, P.; Edwards, A.A.; Szluinska, M.; Skidmore, C.J.; Yoshida, K.; et al. Evidence for complex multigenic inheritance of radiation aml susceptibility in mice revealed using a surrogate phenotypic assay. Carcinogenesis 2006, 27, 311-318.

105. Schottenfeld, D.; Fraumeni, J.F. Cancer Epidemiology and Prevention, 3rd ed.; Oxford University Press: Oxford, UK, 2006; p. 1392.

106. Hartge, P.; Smith, M.T. Environmental and behavioral factors and the risk of non-hodgkin lymphoma. Cancer Epidemiol. Biomarkers Prev. 2007, 16, 367-368.

107. Boice, J.D., Jr. Radiation and non-hodgkin's lymphoma. Cancer Res. 1992, 52, 5489s-5491s.

108. Scientific Committee on the Effects of Atomic Radiation in United Nations. Sources and Effects of Ionizing Radiation: United Nations Scientific Committee on the Effects of Atomic Radiation: Unscear 2000 Report to the General Assembly, with Scientific Annexes; United Nations: New York, USA, 2000.

109. Adami, H.-O.; Hunter, D.J.; Trichopoulos, D. Textbook of Cancer Epidemiology; Oxford University Press: Oxford, UK, 2002; p. 599.

110. Richardson, D.B.; Sugiyama, H.; Wing, S.; Sakata, R.; Grant, E.; Shimizu, Y.; Nishi, N.; Geyer, S.; Soda, M.; Suyama, A.; et al. Positive associations between ionizing radiation and lymphoma mortality among men. Amer. J. Epidemiol. 2009, 169, 969-976.

111. Waalkes, M.P.; Ward, J.M. Carcinogenesis; Raven Press: New York, NY, USA, 1994; p. 478.

112. Okumoto, M.; Nishikawa, R.; Imai, S.; Hilgers, J. Genetic analysis of resistance to radiation lymphomagenesis with recombinant inbred strains of mice. Cancer Res. 1990, 50, 3848-3850.

113. Pattengale, P.K.; Taylor, C.R. Experimental models of lymphoproliferative disease. The mouse as a model for human non-hodgkin's lymphomas and related leukemias. Am. J. Pathol. 1983, $113,237-265$.

114. Pattengale, P.K.; Frith, C.H. Immunomorphologic classification of spontaneous lymphoid cell neoplasms occurring in female BALB/c mice. J. Nat. Cancer Inst. 1983, 70, 169-179.

115. Pattengale, P.; Leder, A.; Kuo, A.; Stewart, T.; Leder, P. Lymphohematopoietic and other malignant neoplasms occurring spontaneously in transgenic mice carrying and expressing MTV/myc fusion genes. Curr. Topics Microbiol. Immunol. 1986, 132, 9-16.

116. Kaplan, H.S.; Brown, M.B.; Paull, J. Influence of postirradiation thymectomy and of thymic implants on lymphoid tumor incidence in C57BL mice. Cancer Res. 1953, 13, 677-680.

117. Okumoto, M.; Nishikawa, R.; Imai, S.; Hilgers, J. Resistance of STS/A mice to lymphoma induction by X-irradiation. J. Radiat. Res. 1989, 30, 135-139.

118. Okumoto, M.; Nishikawa, R.; Takamori, Y.; Iwai, Y.; Iwai, M.; Tsubura, Y. Endogenous Type-C viral expression during lymphoma development in irradiated NFS mice. Radiat. Res. 1985, 104, $153-165$. 
119. Kaplan, H.S. Radiation-induced lymphoid tumors of mice. Acta-Unio Internationalis Contra Cancrum 1952, 7, 849-859.

120. Boniver, J.; Humblet, C.; Rongy, A.M.; Delvenne, C.; Delvenne, P.; Greimers, R.; Thiry, A.; Courtoy, R.; Defresne, M.P. Cellular aspects of the pathogenesis of radiation-induced thymic lymphomas in C57 BL mice (review). In vivo 1990, 4, 41-43.

121. Mori, N.; Takamori, Y. Development of nonthymic lymphomas in thymectomized NFS mice exposed to split-dose X-irradiation. J. Radiat. Res. 1990, 31, 389-395.

122. Saito, Y.; Ochiai, Y.; Kodama, Y.; Tamura, Y.; Togashi, T.; Kosugi-Okano, H.; Miyazawa, T.; Wakabayashi, Y.; Hatakeyama, K.; Wakana, S.; et al. Genetic loci controlling susceptibility to gamma-ray-induced thymic lymphoma. Oncogene 2001, 20, 5243-5247.

123. Meier, H.; Myers, D.D.; Huebner, R.J. Differential effect of a synthetic polyribonucleotide complex on spontaneous and transplanted leukemia in mice. Life Sci. II 1970, 9, 653-659.

124. Brues, A.M. Radiation as a carcinogenic agent. Radiat. Res. 1955, 3, 272-280.

125. Muto, M.; Sado, T.; Hayata, I.; Nagasawa, F.; Kamisaku, H.; Kubo, E. Reconfirmation of indirect induction of radiogenic lymphomas using thymectomized, irradiated B10 mice grafted with neonatal thymuses from Thy 1 congenic donors. Cancer Res. 1983, 43, 3822-3827.

126. Humblet, C.; Greimers, R.; Boniver, J.; Defrense, M.P. Stages in the development of radiation-induced thymic lymphomas in C57 BL/Ka mice: Preleukemic cells become progressively resistant to the tumor preventing effects of a bone marrow graft. Exp. Hematol. 1997, 25, 109-113.

127. Reichert, W.; Buselmaier, W.; Vogel, F. Elimination of X-ray-induced chromosomal aberrations in the progeny of female mice. Mutat. Res. 1984, 139, 87-94.

128. Newcomb, E.W.; Steinberg, J.J.; Pellicer, A. Ras oncogenes and phenotypic staging in $\mathrm{N}$-methylnitrosourea- and gamma-irradiation-induced thymic lymphomas in C57BL/6J mice. Cancer Res. 1988, 48, 5514-5521.

129. Amari, N.M.; Meruelo, D. Murine thymomas induced by fractionated-x-irradiation have specific T-cell receptor rearrangements and characteristics associated with day-15 to -16 fetal thymocytes. Mol. Cell Biol. 1987, 7, 4159-4168.

130. Hogarth, P.M.; Henning, M.M.; McKenzie, I.F. Alloantigenic phenotype of radiation-induced thymomas in the mouse. J. Nat. Cancer Instit. 1982, 69, 619-626.

131. Hogarth, P.M.; Edwards, J.; McKenzie, I.F.; Goding, J.W.; Liew, F.Y. Monoclonal antibodies to the murine Ly-2.1 cell surface antigen. Immunology 1982, 46, 135-144.

132. McMorrow, L.E.; Newcomb, E.W.; Pellicer, A. Identification of a specific marker chromosome early in tumor development in gamma-irradiated C57BL/6J mice. Leukemia 1988, 2, 115-119.

133. Takabatake, T.; Kakinuma, S.; Hirouchi, T.; Nakamura, M.M.; Fujikawa, K.; Nishimura, M.; Oghiso, Y.; Shimada, Y.; Tanaka, K. Analysis of changes in DNA copy number in radiation-induced thymic lymphomas of susceptible $\mathrm{C} 57 \mathrm{BL} / 6$, resistant $\mathrm{C} 3 \mathrm{H}$ and hybrid $\mathrm{F} 1$ mice. Radiat. Res. 2008, 169, 426-436.

134. Sasaki, M. Current status of cytogenetic studies in animal tumors with special reference to nonrandom chromosome changes. Cancer Genet. Cytogenet. 1982, 5, 153-172. 
135. Brathwaite, O.; Bayona, W.; Newcomb, E.W. p53 mutations in C57BL/6J murine thymic lymphomas induced by gamma-irradiation and N-methylnitrosourea. Cancer Res. 1992, 52, 3791-3795.

136. Tomita, N. BCL2 and MYC dual-hit lymphoma/leukemia. J. Clin. Exp. Hematop. 2011, 51, 712.

137. Newcomb, E.W.; Corominas, M.; Bayona, W.; Pellicer, A. Multistage carcinogenesis in murine thymocytes: Involvement of oncogenes, chromosomal imbalances and $\mathrm{T}$ cell growth factor receptor. Anticancer Res. 1989, 9, 1407-1415.

138. Mao, J.H.; Wu, D.; Perez-Losada, J.; Nagase, H.; DelRosario, R.; Balmain, A. Genetic interactions between pten and p53 in radiation-induced lymphoma development. Oncogene 2003, 22, 8379-8385.

139. Liu, C.; Li, B.; Cheng, Y.; Lin, J.; Hao, J.; Zhang, S.; Mitchel, R.E.; Sun, D.; Ni, J.; Zhao, L.; et al. Mir-21 plays an important role in radiation induced carcinogenesis in BALB/c mice by directly targeting the tumor suppressor gene Big-h3. Int. J. Biol. Sci. 2011, 7, 347-363.

140. Lewis, B.P.; Shih, I.H.; Jones-Rhoades, M.W.; Bartel, D.P.; Burge, C.B. Prediction of mammalian microrna targets. Cell 2003, 115, 787-798.

141. Santos, J.; Perez de Castro, I.; Herranz, M.; Pellicer, A.; Fernandez-Piqueras, J. Allelic losses on chromosome 4 suggest the existence of a candidate tumor suppressor gene region of about $0.6 \mathrm{~cm}$ in gamma-radiation-induced mouse primary thymic lymphomas. Oncogene 1996, 12, 669-676.

142. Cleary, H.J.; Boulton, E.; Plumb, M. Allelic loss and promoter hypermethylation of the p15INK4b gene features in mouse radiation-induced lymphoid-but not myeloid-leukaemias. Leukemia 1999, 13, 2049-2052.

143. Cleary, H.J.; Wright, E.; Plumb, M. Specificity of loss of heterozygosity in radiation-induced mouse myeloid and lymphoid leukaemias. Int. J. Radiat. Biol. 1999, 75, 1223-1230.

144. Okano, H.; Saito, Y.; Miyazawa, T.; Shinbo, T.; Chou, D.; Kosugi, S.; Takahashi, Y.; Odani, S.; Niwa, O.; Kominami, R. Homozygous deletions and point mutations of the Ikaros gene in gamma-ray-induced mouse thymic lymphomas. Oncogene 1999, 18, 6677-6683.

145. Shimada, Y.; Nishimura, M.; Kakinuma, S.; Okumoto, M.; Shiroishi, T.; Clifton, K.H.; Wakana, S. Radiation-associated loss of heterozygosity at the Znfnla1 (Ikaros) locus on chromosome 11 in murine thymic lymphomas. Radiat. Res. 2000, 154, 293-300.

146. Shinbo, T.; Matsuki, A.; Matsumoto, Y.; Kosugi, S.; Takahashi, Y.; Niwa, O.; Kominami, R. Allelic loss mapping and physical delineation of a region harboring a putative thymic lymphoma suppressor gene on mouse chromosome 12. Oncogene 1999, 18, 4131-4136.

147. Herranz, M.; Santos, J.; Salido, E.; Fernandez-Piqueras, J.; Serrano, M. Mouse $p 73$ gene maps to the distal part of chromosome 4 and might be involved in the progression of gamma-radiationinduced T-cell lymphomas. Cancer Res. 1999, 59, 2068-2071.

148. Melendez, B.; Malumbres, M.; Perez de Castro, I.; Santos, J.; Pellicer, A.; Fernandez-Piqueras, J. Characterization of the murine $p 19(A R F)$ promoter cpg island and its methylation pattern in primary lymphomas. Carcinogenesis 2000, 21, 817-821.

149. Malumbres, M.; Perez de Castro, I.; Santos, J.; Fernandez Piqueras, J.; Pellicer, A. Hypermethylation of the cell cycle inhibitor p15INK4b 3'-untranslated region interferes with its transcriptional regulation in primary lymphomas. Oncogene 1999, 18, 385-396. 
150. Payne, K.J.; Dovat, S. Ikaros and tumor suppression in acute lymphoblastic leukemia. Crit. Rev. Oncogenesis 2011, 16, 3-12.

151. Gutierrez, A.; Kentsis, A.; Sanda, T.; Holmfeldt, L.; Chen, S.C.; Zhang, J.; Protopopov, A.; Chin, L.; Dahlberg, S.E.; Neuberg, D.S.; et al. The BCL11B tumor suppressor is mutated across the major molecular subtypes of T-cell acute lymphoblastic leukemia. Blood 2011, 118, 4169-4173.

152. Kominami, R. Role of the transcription factor BCL11B in development and lymphomagenesis. Proc. Jpn. Acad. B 2012, 88, 72-87.

153. Kaghad, M.; Bonnet, H.; Yang, A.; Creancier, L.; Biscan, J.C.; Valent, A.; Minty, A.; Chalon, P.; Lelias, J.M.; Dumont, X.; et al. Monoallelically expressed gene related to p53 at $1 p 36$, a region frequently deleted in neuroblastoma and other human cancers. Cell 1997, 90, 809-819.

154. Pei, J.H.; Luo, S.Q.; Zhong, Y.; Chen, J.H.; Xiao, H.W.; Hu, W.X. The association between non-hodgkin lymphoma and methylation of p73. Tumour biol. 2011, 32, 1133-1138.

155. Gronbaek, K.; de Nully Brown, P.; Moller, M.B.; Nedergaard, T.; Ralfkiaer, E.; Moller, P.; Zeuthen, J.; Guldberg, P. Concurrent disruption of p16INK4a and the ARF-p53 pathway predicts poor prognosis in aggressive non-hodgkin's lymphoma. Leukemia 2000, 14, 1727-1735.

156. Mangani, D.; Roberti, A.; Rizzolio, F.; Giordano, A. Emerging molecular networks in burkitt's lymphoma. J. Cell Biochem. 2012, 114, 35-38.

157. Pear, W.S.; Aster, J.C.; Scott, M.L.; Hasserjian, R.P.; Soffer, B.; Sklar, J.; Baltimore, D. Exclusive development of $\mathrm{T}$ cell neoplasms in mice transplanted with bone marrow expressing activated notch alleles. J. Exp. Med. 1996, 183, 2283-2291.

158. Lopez-Nieva, P.; Santos, J.; Fernandez-Piqueras, J. Defective expression of Notch1 and Notch2 in connection to alterations of $c-M y c$ and Ikaros in gamma-radiation-induced mouse thymic lymphomas. Carcinogenesis 2004, 25, 1299-1304.

159. Piskorowska, J.; Gajewska, M.; Szymanska, H.; Krysiak, E.; Quan, L.; Grygalewicz, B.; Skurzak, H.M.; Czarnomska, A.; Pienkowska-Grela, B.; Demant, P. Susceptibility loci and chromosomal abnormalities in radiation induced hematopoietic neoplasms in mice. J. Rad. Res. 2011, 52, $147-158$.

160. Davila, M.; Foster, S.; Kelsoe, G.; Yang, K. A role for secondary V(D)J recombination in oncogenic chromosomal translocations? Advan. Cancer Res. 2001, 81, 61-92.

161. Marculescu, R.; Le, T.; Bocskor, S.; Mitterbauer, G.; Chott, A.; Mannhalter, C.; Jaeger, U.; Nadel, B. Alternative end-joining in follicular lymphomas' $\mathrm{t}(14 ; 18)$ translocation. Leukemia 2002, 16, 120-126.

162. Marculescu, R.; Le, T.; Simon, P.; Jaeger, U.; Nadel, B. V(D)J-mediated translocations in lymphoid neoplasms: A functional assessment of genomic instability by cryptic sites. J. Exp. Med. 2002, 195, 85-98.

163. Kominami, R.; Niwa, O. Radiation carcinogenesis in mouse thymic lymphomas. Cancer Sci. 2006, 97, 575-581.

164. Kaplan, H.S. The role of radiation on experimental leukemogenesis. Natl. Cancer Inst. Monogr. 1964, 14, 207-220.

165. Sado, T.; Kamisaku, H.; Kubo, E. Bone marrow-thymus interactions during thymic lymphomagenesis induced by fractionated radiation exposure in B10 mice: Analysis using bone marrow transplantation between Thy 1 congenic mice. J. Radiat. Res. 1991, 32, 168-180. 
166. Boniver, J.; Humblet, C.; Rongy, A.M.; Delvenne, C.; Delvenne, P.; Greimers, R.; Thiry, A.; Courtoy, R.; Defresne, M.P. Cellular events in radiation-induced lymphomagenesis. Int. J. Radiat. Biol. 1990, 57, 693-698.

167. Kaplan, H.S.; Hirsch, B.B.; Brown, M.B. Indirect induction of lymphomas in irradiated mice. IV. Genetic evidence of the origin of the tumor cells from the thymic grafts. Cancer Res. 1956, 16, 434-436.

168. Kaplan, H.S.; Carnes, W.H.; Brown, M.B.; Hirsch, B.B. Indirect induction of lymphomas in irradiated mice. I. Tumor incidence and morphology in mice bearing nonirradiated thymic grafts. Cancer Res. 1956, 16, 422-425.

169. Kaplan, H.S.; Brown, M.B.; Hirsch, B.B.; Carnes, W.H. Indirect induction of lymphomas in irradiated mice. II. Factor of irradiation of the host. Cancer Res. 1956, 16, 426-428.

170. Muto, M.; Kubo, E.; Sado, T. Development of prelymphoma cells committed to thymic lymphomas during radiation-induced thymic lymphomagenesis in B10 mice. Cancer Res. 1987, 47, 3469-3472.

171. Little, J.B. Radiation carcinogenesis. Carcinogenesis 2000, 21, 397-404.

172. Redpath, J.L.; Gutierrez, M. Kinetics of induction of reactive oxygen species during the post-irradiation expression of neoplastic transformation in vitro. Int. J. Radiat. Biol. 2001, 77, 1081-1085.

173. Tamura, Y.; Maruyama, M.; Mishima, Y.; Fujisawa, H.; Obata, M.; Kodama, Y.; Yoshikai, Y.; Aoyagi, Y.; Niwa, O.; Schaffner, W.; et al. Predisposition to mouse thymic lymphomas in response to ionizing radiation depends on variant alleles encoding metal-responsive transcription factor-1 (Mtf-1). Oncogene 2005, 24, 399-406.

174. Maruyama, M.; Yamamoto, T.; Kohara, Y.; Katsuragi, Y.; Mishima, Y.; Aoyagi, Y.; Kominami, R. Mtf-1 lymphoma-susceptibility locus affects retention of large thymocytes with high ros levels in mice after gamma-irradiation. Biochem. Biophys. Res. Commun. 2007, 354, 209-215.

175. Lichtlen, P.; Wang, Y.; Belser, T.; Georgiev, O.; Certa, U.; Sack, R.; Schaffner, W. Target gene search for the metal-responsive transcription factor Mtf-1. Nucleic Acids Res. 2001, 29, 1514-1523.

176. Sun, L.; Goodman, P.A.; Wood, C.M.; Crotty, M.L.; Sensel, M.; Sather, H.; Navara, C.; Nachman, J.; Steinherz, P.G.; Gaynon, P.S.; et al. Expression of aberrantly spliced oncogenic Ikaros isoforms in childhood acute lymphoblastic leukemia. J. Clin. Oncol. 1999, 17, 3753-3766.

177. Sun, L.; Crotty, M.L.; Sensel, M.; Sather, H.; Navara, C.; Nachman, J.; Steinherz, P.G.; Gaynon, P.S.; Seibel, N.; Mao, C.; et al. Expression of dominant-negative Ikaros isoforms in T-cell acute lymphoblastic leukemia. Clin. Cancer Res. 1999, 5, 2112-2120.

178. Ruiz, A.; Jiang, J.; Kempski, H.; Brady, H.J. Overexpression of the Ikaros 6 isoform is restricted to $\mathrm{t}(4 ; 11)$ acute lymphoblastic leukaemia in children and infants and has a role in B-cell survival. Brit. J. Haematol. 2004, 125, 31-37.

179. Mullighan, C.G.; Miller, C.B.; Radtke, I.; Phillips, L.A.; Dalton, J.; Ma, J.; White, D.; Hughes, T.P.; Le Beau, M.M.; Pui, C.H.; et al. BCR-ABL1 lymphoblastic leukaemia is characterized by the deletion of Ikaros. Nature 2008, 453, 110-114. 
180. Tsuji, H.; Ishii-Ohba, H.; Katsube, T.; Ukai, H.; Aizawa, S.; Doi, M.; Hioki, K.; Ogiu, T. Involvement of illegitimate $\mathrm{V}(\mathrm{D}) \mathrm{J}$ recombination or microhomology-mediated nonhomologous end-joining in the formation of intragenic deletions of the Notchl gene in mouse thymic lymphomas. Cancer Res. 2004, 64, 8882-8890.

181. Weng, A.P.; Ferrando, A.A.; Lee, W.; Morris, J.P.T.; Silverman, L.B.; Sanchez-Irizarry, C.; Blacklow, S.C.; Look, A.T.; Aster, J.C. Activating mutations of Notch1 in human T cell acute lymphoblastic leukemia. Science 2004, 306, 269-271.

182. Zuurbier, L.; Petricoin, E.F., 3rd; Vuerhard, M.J.; Calvert, V.; Kooi, C.; Buijs-Gladdines, J.G.; Smits, W.K.; Sonneveld, E.; Veerman, A.J.; Kamps, W.A.; et al. The significance of PTEN and AKT aberrations in pediatric T-cell acute lymphoblastic leukemia. Haematologica 2012, 97, 1405-1413.

183. Mulligan, C.S.; Best, O.G.; Mulligan, S.P.; Consortium on Chronic Lymphocytic Leukaemia Australian Research. The precursor of chronic lymphocytic leukemia. N. Engl. J. Med. 2009, 360, 2575-2576.

184. Okuda, T.; Shurtleff, S.A.; Valentine, M.B.; Raimondi, S.C.; Head, D.R.; Behm, F.; Curcio-Brint, A.M.; Liu, Q.; Pui, C.H.; Sherr, C.J.; et al. Frequent deletion of p16INK4a/MTS1 and p15INK4b/MTS2 in pediatric acute lymphoblastic leukemia. Blood 1995, 85, 2321-2330.

185. Lopez-Nieva, P.; Vaquero, C.; Fernandez-Navarro, P.; Gonzalez-Sanchez, L.; Villa-Morales, M.; Santos, J.; Esteller, M.; Fernandez-Piqueras, J. EPHA7, a new target gene for 6q deletion in T-cell lymphoblastic lymphomas. Carcinogenesis 2012, 33, 452-458.

186. Carbone, D. Smoking and cancer. Amer. J. Med. 1992, 93, 13S-17S.

187. Coggle, J.E.; Lambert, B.E.; Moores, S.R. Radiation effects in the lung. Environ. Health Perspect. 1986, 70, 261-291.

188. Griem, M.L.; Kleinerman, R.A.; Boice, J.D., Jr.; Stovall, M.; Shefner, D.; Lubin, J.H. Cancer following radiotherapy for peptic ulcer. J. Nat. Cancer Instit. 1994, 86, 842-849.

189. Darby, S.C.; Doll, R.; Gill, S.K.; Smith, P.G. Long term mortality after a single treatment course with X-rays in patients treated for ankylosing spondylitis. Brit. J. Cancer 1987, 55, 179-190.

190. Preston, D.L.; Ron, E.; Tokuoka, S.; Funamoto, S.; Nishi, N.; Soda, M.; Mabuchi, K.; Kodama, K. Solid cancer incidence in atomic bomb survivors: 1958-1998. Radiat. Res. 2007, 168, 1-64.

191. Egawa, H.; Furukawa, K.; Preston, D.; Funamoto, S.; Yonehara, S.; Matsuo, T.; Tokuoka, S.; Suyama, A.; Ozasa, K.; Kodama, K.; et al. Radiation and smoking effects on lung cancer incidence by histological types among atomic bomb survivors. Radiat. Res. 2012, 178, 191-201.

192. Travis, L.B. Therapy-associated solid tumors. Acta Oncologica 2002, 41, 323-333.

193. Travis, L.B.; Gospodarowicz, M.; Curtis, R.E.; Clarke, E.A.; Andersson, M.; Glimelius, B.; Joensuu, T.; Lynch, C.F.; van Leeuwen, F.E.; Holowaty, E.; et al. Lung cancer following chemotherapy and radiotherapy for hodgkin's disease. J. Nat. Cancer Instit. 2002, 94, 182-192.

194. Travis, L.B.; Curtis, R.E.; Boice, J.D., Jr. Late effects of treatment for childhood hodgkin's disease. N. Engl. J. Med. 1996, 335, 352-353.

195. Prochazka, M.; Granath, F.; Ekbom, A.; Shields, P.G.; Hall, P. Lung cancer risks in women with previous breast cancer. Eur. J. Cancer 2002, 38, 1520-1525. 
196. Kirova, Y.M.; Gambotti, L.; de Rycke, Y.; Vilcoq, J.R.; Asselain, B.; Fourquet, A. Risk of second malignancies after adjuvant radiotherapy for breast cancer: A large-scale, single-institution review. Int. J. Radiat. Oncol. Biol. Phys. 2007, 68, 359-363.

197. Endoh, D.; Suzuki, A.; Kuwabara, M.; Satoh, H.; Sato, F. Circadian variation in lung tumor induction with X-rays in mice. J. Radiat. Res. 1987, 28, 186-189.

198. Hashimoto, N.; Endoh, D.; Kuwabara, M.; Satoh, H.; Sato, F. Induction of lung tumors in C3H strain mice after single or fractionated irradiation with X-rays. J. Vet. Med. Sci. 1994, 56, 493-498.

199. Hashimoto, N.; Endoh, D.; Kuwabara, M.; Satoh, H.; Sato, F. Dose and dose-splitting effects of X-rays on lung tumour induction in mice. Int. J. Radiat. Biol. 1990, 58, 351-360.

200. Focan, C. Chronobiological concepts underlying the chronotherapy of human lung cancer. Chronobiol. Int. 2002, 19, 253-273.

201. Yuhas, J.M.; Walker, A.E. Exposure-response curve for radiation-induced lung tumors in the mouse. Radiat. Res. 1973, 54, 261-273.

202. Ullrich, R.L.; Jernigan, M.C.; Adams, L.M. Induction of lung tumors in rfm mice after localized exposures to X rays or neutrons. Radiat. Res. 1979, 80, 464-473.

203. Ullrich, R.L. Tumor induction in BALB/c female mice after fission neutron or gamma irradiation. Radiat. Res. 1983, 93, 506-515.

204. Ullrich, R.L.; Jernigan, M.C.; Satterfield, L.C.; Bowles, N.D. Radiation carcinogenesis: Time-dose relationships. Radiat. Res. 1987, 111, 179-184.

205. Coggle, J.E. The role of animal models in radiation lung carcinogenesis. Radiat. Environ. Biophys. 1991, 30, 239-241.

206. Grahn, D.; Lombard, L.S.; Carnes, B.A. The comparative tumorigenic effects of fission neutrons and cobalt-60 gamma rays in the B6CF1 mouse. Radiat. Res. 1992, 129, 19-36.

207. Zhang, Y.; Woloschak, G.E. $R b$ and $p 53$ gene deletions in lung adenocarcinomas from irradiated and control mice. Radiat. Res. 1997, 148, 81-89.

208. Zhang, Y.; Woloschak, G.E. Detection of codon 12 point mutations of the K-ras gene from mouse lung adenocarcinoma by “enriched” PCR. Int. J. Radiat. Biol. 1998, 74, 43-51.

209. Tuveson, D.A.; Jacks, T. Modeling human lung cancer in mice: Similarities and shortcomings. Oncogene 1999, 18, 5318-5324.

210. Salgia, R.; Skarin, A.T. Molecular abnormalities in lung cancer. J. Clin. Oncol. 1998, 16, 1207-1217.

211. Sekido, Y.; Fong, K.M.; Minna, J.D. Progress in understanding the molecular pathogenesis of human lung cancer. Biochim. Biophys. Acta 1998, 1378, F21-59.

212. D’Amico, D.; Carbone, D.; Mitsudomi, T.; Nau, M.; Fedorko, J.; Russell, E.; Johnson, B.; Buchhagen, D.; Bodner, S.; Phelps, R.; et al. High frequency of somatically acquired p53 mutations in small-cell lung cancer cell lines and tumors. Oncogene 1992, 7, 339-346.

213. Hensel, C.H.; Xiang, R.H.; Sakaguchi, A.Y.; Naylor, S.L. Use of the single strand conformation polymorphism technique and PCR to detect p53 gene mutations in small cell lung cancer. Oncogene 1991, 6, 1067-1071.

214. Takahashi, T.; Takahashi, T.; Suzuki, H.; Hida, T.; Sekido, Y.; Ariyoshi, Y.; Ueda, R. The p53 gene is very frequently mutated in small-cell lung cancer with a distinct nucleotide substitution pattern. Oncogene 1991, 6, 1775-1778. 
215. Sameshima, Y.; Matsuno, Y.; Hirohashi, S.; Shimosato, Y.; Mizoguchi, H.; Sugimura, T.; Terada, M.; Yokota, J. Alterations of the $p 53$ gene are common and critical events for the maintenance of malignant phenotypes in small-cell lung carcinoma. Oncogene 1992, 7, 451-457.

216. Symonds, H.; Krall, L.; Remington, L.; Saenz-Robles, M.; Lowe, S.; Jacks, T.; van Dyke, T. P53-dependent apoptosis suppresses tumor growth and progression in vivo. Cell 1994, 78, 703711.

217. Sherr, C.J.; McCormick, F. The $R b$ and $p 53$ pathways in cancer. Cancer cell 2002, 2, 103-112.

218. Olsson, A.Y.; Feber, A.; Edwards, S.; Te Poele, R.; Giddings, I.; Merson, S.; Cooper, C.S. Role of E2F3 expression in modulating cellular proliferation rate in human bladder and prostate cancer cells. Oncogene 2007, 26, 1028-1037.

219. Das, S.K.; Hashimoto, T.; Shimizu, K.; Yoshida, T.; Sakai, T.; Sowa, Y.; Komoto, A.; Kanazawa, K. Fucoxanthin induces cell cycle arrest at G0/G1 phase in human colon carcinoma cells through up-regulation of p21WAF1/Cip1. Biochim. Biophys. Acta 2005, 1726, 328-335.

220. Vojtek, A.B.; Der, C.J. Increasing complexity of the ras signaling pathway. J. Biol. Chem. 1998, 273, 19925-19928.

221. Califano, R.; Landi, L.; Cappuzzo, F. Prognostic and predictive value of K-ras mutations in non-small cell lung cancer. Drugs 2012, 72, 28-36.

222. Bongiorno, P.F.; Whyte, R.I.; Lesser, E.J.; Moore, J.H.; Orringer, M.B.; Beer, D.G. Alterations of $K$-ras, p53, and erbB-2/neu in human lung adenocarcinomas. J. Thorac. Cardiovasc. Surg. 1994, 107, 590-595.

223. Boice, J.D., Jr.; Preston, D.; Davis, F.G.; Monson, R.R. Frequent chest X-ray fluoroscopy and breast cancer incidence among tuberculosis patients in massachusetts. Radiat. Res. 1991, 125, 214-222.

224. Bhatia, S.; Robison, L.L.; Oberlin, O.; Greenberg, M.; Bunin, G.; Fossati-Bellani, F.; Meadows, A.T. Breast cancer and other second neoplasms after childhood hodgkin's disease. N. Engl. J. Med. 1996, 334, 745-751.

225. Sankila, R.; Garwicz, S.; Olsen, J.H.; Dollner, H.; Hertz, H.; Kreuger, A.; Langmark, F.; Lanning, M.; Moller, T.; Tulinius, H. Risk of subsequent malignant neoplasms among 1,641 hodgkin's disease patients diagnosed in childhood and adolescence: A population-based cohort study in the five nordic countries. Association of the nordic cancer registries and the nordic society of pediatric hematology and oncology. J. Clin. Oncol. 1996, 14, 1442-1446.

226. Stovall, M.; Smith, S.A.; Langholz, B.M.; Boice, J.D., Jr.; Shore, R.E.; Andersson, M.; Buchholz, T.A.; Capanu, M.; Bernstein, L.; Lynch, C.F.; et al. Dose to the contralateral breast from radiotherapy and risk of second primary breast cancer in the wecare study. Int. J. Radiat. Oncol. Biol. Phys. 2008, 72, 1021-1030.

227. Brooks, J.D.; Boice, J.D., Jr.; Stovall, M.; Reiner, A.S.; Bernstein, L.; John, E.M.; Lynch, C.F.; Mellemkjaer, L.; Knight, J.A.; Thomas, D.C.; et al. Reproductive status at first diagnosis influences risk of radiation-induced second primary contralateral breast cancer in the wecare study. Int. J. Radiat. Oncol. Biol. Phys. 2012.

228. Thomas, D.B.; Rosenblatt, K.; Jimenez, L.M.; McTiernan, A.; Stalsberg, H.; Stemhagen, A.; Thompson, W.D.; Curnen, M.G.; Satariano, W.; Austin, D.F.; et al. Ionizing radiation and breast cancer in men (United States). Cancer Causes Control 1994, 5, 9-14. 
229. Ronckers, C.M.; Erdmann, C.A.; Land, C.E. Radiation and breast cancer: A review of current evidence. Breast Cancer Res. 2005, 7, 21-32.

230. Imaoka, T.; Nishimura, M.; Iizuka, D.; Daino, K.; Takabatake, T.; Okamoto, M.; Kakinuma, S.; Shimada, Y. Radiation-induced mammary carcinogenesis in rodent models: What's different from chemical carcinogenesis? J. Radiat. Res. 2009, 50, 281-293.

231. Medina, D. The preneoplastic phenotype in murine mammary tumorigenesis. J. Mammary Gland Biol. Neoplasi. 2000, 5, 393-407.

232. Finerty, J.C.; Binhammer, R.T.; Schneider, M.; Cunningham, A.W. Neoplasms in rats exposed to single-dose total-body X radiation. J. Nat. Cancer Instit. 1953, 14, 149-157.

233. Shellabarger, C.J.; Cronkite, E.P.; Bond, V.P.; Lippincott, S.W. The occurrence of mammary tumors in the rat after sublethal whole-body irradiation. Radiat. Res. 1957, 6, 501-512.

234. Medina, D. Of mice and women: A short history of mouse mammary cancer research with an emphasis on the paradigms inspired by the transplantation method. Cold Spring Harb. Perspect. Biol. 2010, 2, a004523, doi: 10.1101/cshperspect.a004523.

235. Ullrich, R.L.; Preston, R.J. Radiation induced mammary cancer. J. Radiat. Res. 1991, 32, 104-109.

236. Deome, K.B.; Faulkin, L.J., Jr.; Bern, H.A.; Blair, P.B. Development of mammary tumors from hyperplastic alveolar nodules transplanted into gland-free mammary fat pads of female $\mathrm{C} 3 \mathrm{H}$ mice. Cancer Res. 1959, 19, 515-520.

237. Barcellos-Hoff, M.H. Radiation-induced transforming growth factor beta and subsequent extracellular matrix reorganization in murine mammary gland. Cancer Res. 1993, 53, 3880-3886.

238. Barcellos-Hoff, M.H. The potential influence of radiation-induced microenvironments in neoplastic progression. J. Mammary Gland Biol. Neoplasi. 1998, 3, 165-175.

239. Barcellos-Hoff, M.H. How tissues respond to damage at the cellular level: Orchestration by transforming growth factor-[1] (tgf-[1]). BJR Suppl. 2005, 27, 123-127.

240. Barcellos-Hoff, M.H. Integrative radiation carcinogenesis: Interactions between cell and tissue responses to DNA damage. Semin. Cancer Biol. 2005, 15, 138-148.

241. Yu, Y.; Okayasu, R.; Weil, M.M.; Silver, A.; McCarthy, M.; Zabriskie, R.; Long, S.; Cox, R.; Ullrich, R.L. Elevated breast cancer risk in irradiated BALB/c mice associates with unique functional polymorphism of the prkdc (DNA-dependent protein kinase catalytic subunit) gene. Cancer Res. 2001, 61, 1820-1824.

242. DeOme, K.B.; Miyamoto, M.J.; Osborn, R.C.; Guzman, R.C.; Lum, K. Detection of inapparent nodule-transformed cells in the mammary gland tissues of virgin female BALB/cfC $3 \mathrm{H}$ mice. Cancer Res. 1978, 38, 2103-2111.

243. Ethier, S.P.; Ullrich, R.L. Factors influencing expression of mammary ductal dysplasia in cell dissociation-derived murine mammary outgrowths. Cancer Res. 1984, 44, 4523-4527.

244. Ethier, S.P.; Ullrich, R.L. Detection of ductal dysplasia in mammary outgrowths derived from carcinogen-treated virgin female BALB/c mice. Cancer Res. 1982, 42, 1753-1760.

245. Ethier, S.P.; Adams, L.M.; Ullrich, R.L. Morphological and histological characteristics of mammary dysplasias occurring in cell dissociation-derived murine mammary outgrowths. Cancer Res. 1984, 44, 4517-4522. 
246. Ethier, S.P.; Ullrich, R.L. Induction of mammary tumors in virgin female BALB/c mice by single low doses of 7,12-dimethylbenz[a]anthracene. Jo. Nat. Cancer Instit. 1982, 69, 1199-1203.

247. Ullrich, R.L.; Bowles, N.D.; Satterfield, L.C.; Davis, C.M. Strain-dependent susceptibility to radiation-induced mammary cancer is a result of differences in epithelial cell sensitivity to transformation. Radiat. Res. 1996, 146, 353-355.

248. Barcellos-Hoff, M.H.; Ravani, S.A. Irradiated mammary gland stroma promotes the expression of tumorigenic potential by unirradiated epithelial cells. Cancer Res. 2000, 60, 1254-1260.

249. Danielson, M. Hemodynamic effects of diuretic therapy in hypertension. Acta pharmacol. Toxicol. 1984, 54, 33-36.

250. Nguyen, D.H.; Oketch-Rabah, H.A.; Illa-Bochaca, I.; Geyer, F.C.; Reis-Filho, J.S.; Mao, J.H.; Ravani, S.A.; Zavadil, J.; Borowsky, A.D.; Jerry, D.J.; et al. Radiation acts on the microenvironment to affect breast carcinogenesis by distinct mechanisms that decrease cancer latency and affect tumor type. Cancer cell 2011, 19, 640-651.

251. Barcellos-Hoff, M.H.; Brooks, A.L. Extracellular signaling through the microenvironment: A hypothesis relating carcinogenesis, bystander effects, and genomic instability. Radiat. Res. 2001, $156,618-627$.

252. Barcellos-Hoff, M.H.; Park, C.; Wright, E.G. Radiation and the microenvironmentTumorigenesis and therapy. Nat. Rev. Cancer 2005, 5, 867-875.

253. Barcellos-Hoff, M.H.; Medina, D. New highlights on stroma-epithelial interactions in breast cancer. Breast Cancer Res. 2005, 7, 33-36.

254. Alberts, B. Molecular Biology of the Cell, 5th ed.; Garland Science: New York, NY, USA, 2008.

255. Andarawewa, K.L.; Paupert, J.; Pal, A.; Barcellos-Hoff, M.H. New rationales for using tgfbeta inhibitors in radiotherapy. Int. J. Radiat. Biol. 2007, 83, 803-811.

256. Andarawewa, K.L.; Erickson, A.C.; Chou, W.S.; Costes, S.V.; Gascard, P.; Mott, J.D.; Bissell, M.J.; Barcellos-Hoff, M.H. Ionizing radiation predisposes nonmalignant human mammary epithelial cells to undergo transforming growth factor beta induced epithelial to mesenchymal transition. Cancer Res. 2007, 67, 8662-8670.

257. Castiglioni, F.; Terenziani, M.; Carcangiu, M.L.; Miliano, R.; Aiello, P.; Bertola, L.; Triulzi, T.; Gasparini, P.; Camerini, T.; Sozzi, G.; et al. Radiation effects on development of HER2-positive breast carcinomas. Clin. Cancer Res. 2007, 13, 46-51.

258. Arima, Y.; Hayashi, H.; Sasaki, M.; Hosonaga, M.; Goto, T.M.; Chiyoda, T.; Kuninaka, S.; Shibata, T.; Ohata, H.; Nakagama, H.; et al. Induction of ZEB proteins by inactivation of $R b$ protein is key determinant of mesenchymal phenotype of breast cancer. J. Biol. Chem. 2012, 287, 7896-7906.

(C) 2013 by the authors; licensee MDPI, Basel, Switzerland. This article is an open access article distributed under the terms and conditions of the Creative Commons Attribution license (http://creativecommons.org/licenses/by/3.0/). 